\title{
HOW DO THEY DO IT? PERSPECTIVES ON BEING AN EDUCATIONAL ASSISTANT IN AN ONTARIO CLASSROOM
}

by

Patricia Marie Hodgson, Honours B.A., Ryerson University, 2009

\author{
A Major Research Paper \\ Presented to Ryerson University \\ in partial fulfillment of the \\ requirements for the degree of \\ Masters of Arts \\ in the program of \\ Early Childhood Studies
}

Toronto, Ontario, Canada, 2010

(C) Patricia Marie Hodgson, 2010 
I hereby declare that I am the sole author of this major research paper.

I authorize Ryerson University to lend this paper to other institutions or individuals for the purpose of scholarly research.

I further authorize Ryerson University to reproduce this paper by photocopying, or by other means, in total or in part, at the request of other institutions or individuals for the purpose of scholarly research. 


\title{
HOW DO THEY DO IT? PERSPECTIVES ON BEING AN EDUCATIONAL ASSISTANT IN AN ONTARIO CLASSROOM \\ (C) Patricia Marie Hodgson, 2010
}

\author{
Masters of Arts \\ Early Childhood Studies \\ Ryerson University
}

\begin{abstract}
This qualitative study examined the roles and responsibilities of educational assistants from their own perspectives. Five educational assistants kept written journals and each participant was interviewed once. Findings were interpreted through a critical lens which allowed an examination of the relationships within the hierarchal power structure of the school system and where the educational assistants were situated. A grounded theory approach explained the factors which influenced the perspectives of the participants on being an educational assistant in an Ontario classroom. These factors were identified and organized in five major categories: 1) roles and responsibilities, 2) relationships, 3) communication, 4) changes, and 5) training. The interrelationships between these categories highlighted the complex nature of the role of the educational assistant. This study concluded that relationships and communication had a major influence on the perspectives of the educational assistants.
\end{abstract}

Key words: educational assistant, roles and responsibilities, inclusive and segregated classrooms, educational assistant's perspectives 


\section{Acknowledgements}

I would like to thank Dr. Rachel Langford for guiding me through this process. Without her patience, knowledge and dedication I am certain I would not have been able to complete the MRP. I would also like to thank Dr. Kathryn Underwood and Dr. Angela Valeo for their time and insightful contributions.

I would like to thank the hard-working educational assistants who agreed to share their stories with me.

My parents, John and Pat Wynne, were among my biggest supporters. They have given me the gift of thinking anything is possible and the confidence to follow my dreams.

Thank you to my sister Kathleen, who has been the greatest role model a woman could have; strength, intelligence and an endless curiosity to learn and grow. Thank you for all of your insight and encouragement. Thank you to my sisters Evie and Ann for being incredibly supportive throughout this process.

My children, Katy, Charlotte, Tim and Lizzie, thank you for giving me the time and space to realize this major accomplishment.

To Brenda Frey, Colleen Thornton and Carolynne Warton, thank you for the constant support and conversations that helped me through the difficult moments. I do not think I could have managed without the encouragement of my classmates.

And finally, to my husband Douglas, thank you for the late afternoon conversations on the porch. It was very important for me to have you with me throughout this process, thank you for being a good friend. 


\section{Table of Contents}

Author's Declaration

Abstract

Acknowledgements

List of Tables

List of Appendices

\section{CHAPTER I}

Introduction. 1

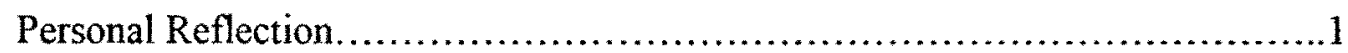

Policy Context.......................................................... 4

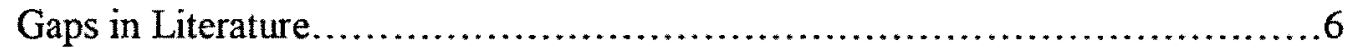

Theoretical and Contextual Framework................................... 8

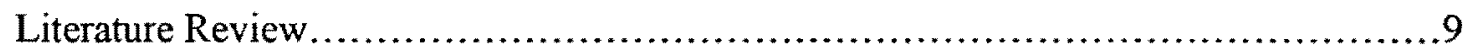

Perspectives on Role Clarity, Job Satisfaction and Job Retention.................. 9

Bane or Blessing: The Educational Assistant in the Classroom................. 13

EAs in the General Education Classroom................................ 15

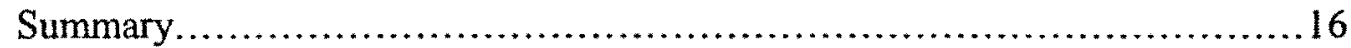

Research Questions.................................................. 17

\section{CHAPTER II}

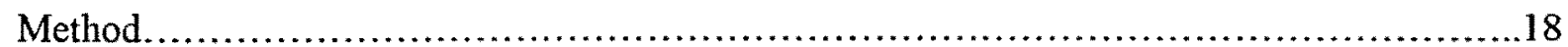

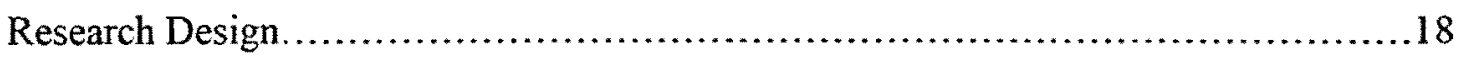

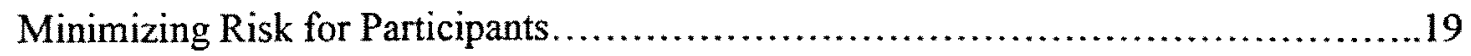

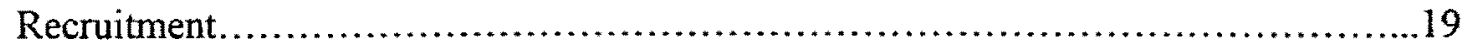

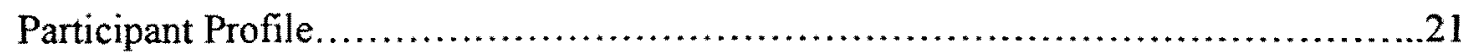


Data Collection. .24

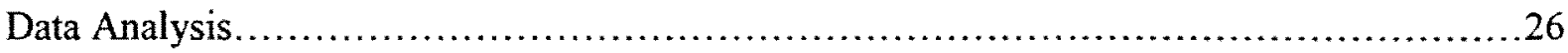

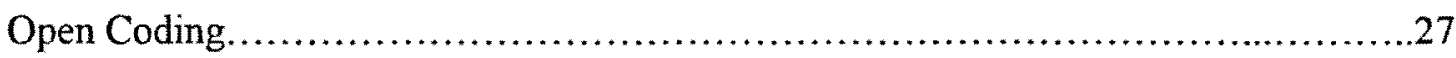

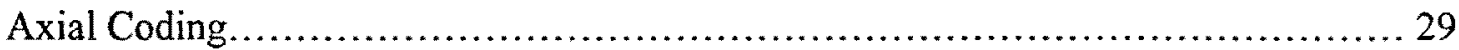

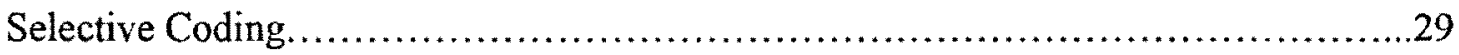

Credibility, Authenticity and Trustworthiness......................................30

\section{CHAPTER III}

Findings......

Major Categories ......................................................................

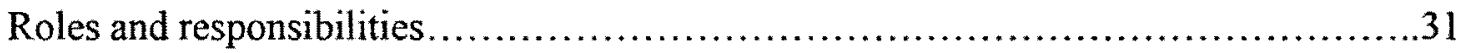

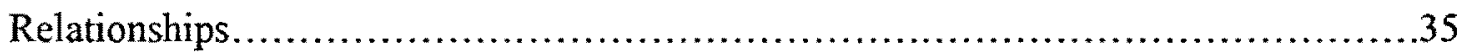

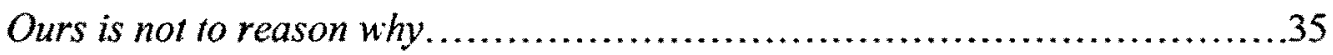

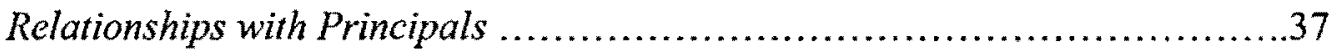

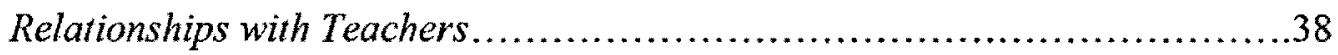

You get three days if she dies..............................................40

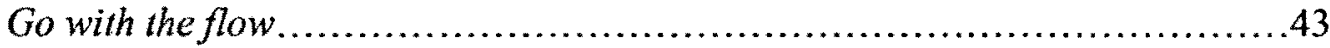

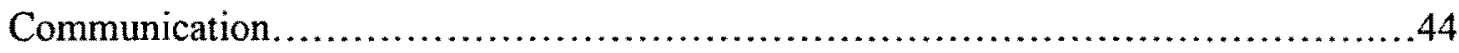

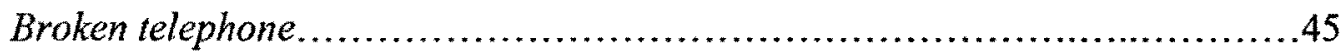

Is the school board aware of who really gets the support? .......................46

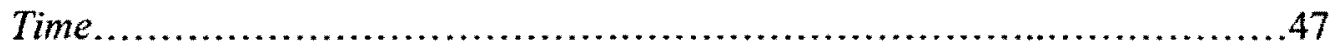

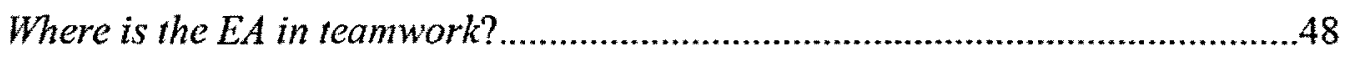

EAs' communication with teachers, principals and parents....................49

EAs communicating with EAs ..........................................51

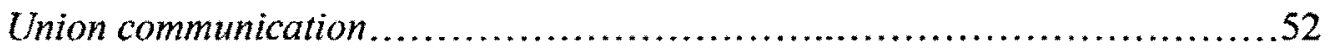

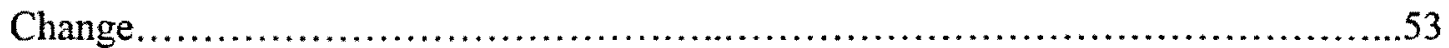


Changing from segregated to general education classroom..................53

Scheduling changes.................................................56

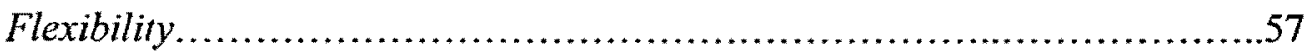

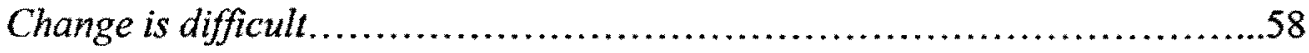

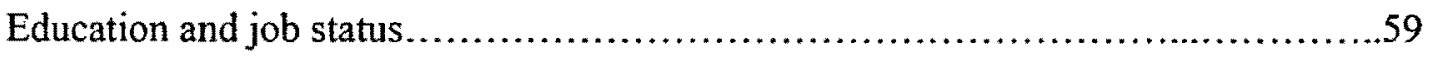

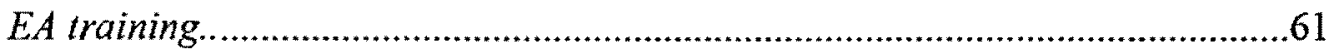

Interrelationships between the categories......................................63

\section{CHAPTER IV}

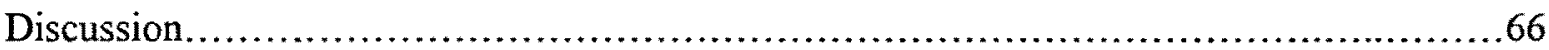

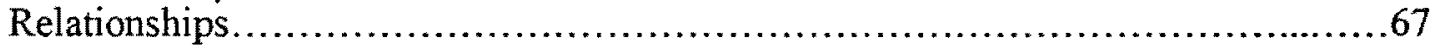

Deep feelings of powerlessness.......................................68

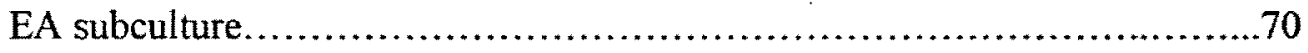

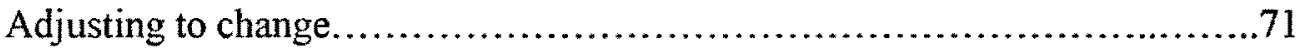

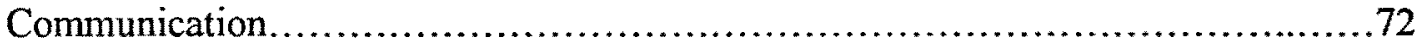

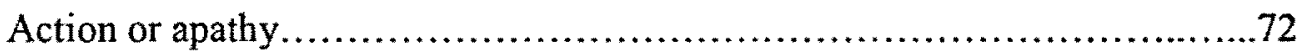

Dysfunctional communication......................................... 73

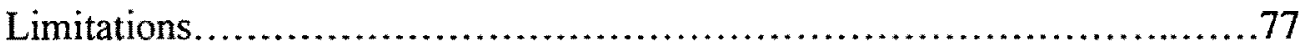

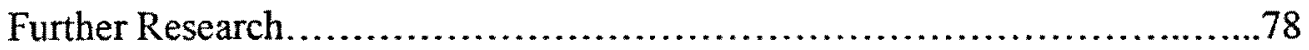

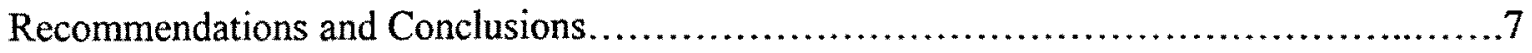

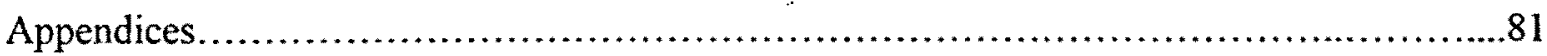

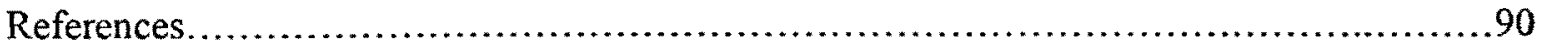




\section{List of Tables}

Table 1. Summary of Participant Profile ............................................2. 24

Table 2. Summary of EA's Roles and Responsibilities...............................34

Table 3. Main Categories and the Supporting Subcategories........................64

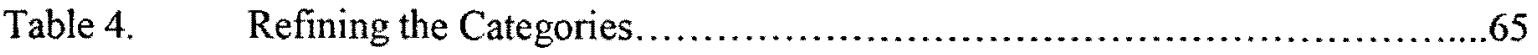




\section{List of Appendices}

Appendix A. Job Fact Sheet (Simcoe County District School Board) .....................81

Appendix B. Ryerson University Research Study Consent Form.........................83

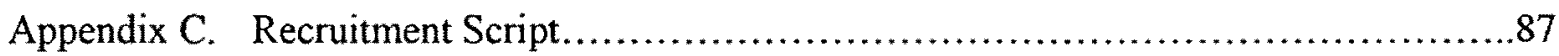

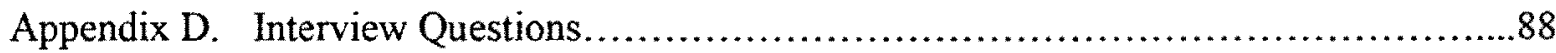




\section{CHAPTER I}

\section{Introduction}

Quality education for all students is one of the primary goals for our education system in Ontario (Ministry of Education, 2005). The presence of educational assistants in the classroom is one of the ways the education system has attempted to meet this goal. There are several issues which have influenced my decision to investigate the perspectives of being an educational assistant in the classroom: my own experiences, the lack of definition in the role of the educational assistant and critical gaps in the existing body of literature.

\section{Personal Reflection}

The educational assistant (EA) is a member of the support staff employed by the school board. According to the Simcoe County District School Board Job Fact Sheet (SCDSB \& OPSEU, 2008), created as part of the collective agreement between The Ontario Public Service Employees Union (OPSEU) and the Simcoe County District School Board, the educational assistant is hired specifically to provide support to children with special needs within a school setting under the supervision of the teacher. For example, according to the EA's job description they must: keep and maintain records of student's activity, behaviour and progress under the direction of the teacher; be aware of special information pertaining to the student, assist the teacher in the delivery of programs, assist the teacher with the development of special programs and activities as appropriate to the needs of the program and to the individual student (SCDSB \& OPSEU, 2008). There are a total of 16 specific duties listed on the Job Fact Sheet (see Appendix A). Many of the duties assigned are dependent on the teacher's supervision or 
direction. The EA must report all observations of the students to the teacher in charge and participate as required in staff discussions. The principal may assign special duties as they arise.

I have spent several years working as an educational assistant in the Ontario public school system. I began as a member of the supply pool. I was on call and filled in for other EAs who were away. At first I was challenged by the demands of the job. At the same time I loved the diversity in the children, classrooms and schools. As I became familiar with many of the schools, they would call me on a regular basis and I began to feel as though I were part of the larger group of EAs. Eventually I was hired as a fulltime employee and I was pleased. As questions came up about scheduling changes, class assignments, supervising children alone and safety plans, I would ask the other EAs. But often there would not be a clear answer. The unanswered questions became part of my growing curiosity about the job; a job which seemed to be very important to the management of the school. I can remember asking why no one spoke up when there were serious issues to be discussed. The EA works with the general education teacher who will be referred to in this paper as, teacher, and the special education resource teachers (SERT) work together to support students with special needs.

I often felt ill equipped to perform my duties, in part because I had no idea what my duties were. The tasks were usually explained to me by the other EAs. I knew that the teachers were sometimes at a loss as well and at times I felt very alone. In a classroom where the children's needs were very high, I had three nine year old boys assigned to my care. One day, as the French teacher arrived to the portable she told me, "I don't care where you take them; just get them out of this classroom because I cannot teach when they are here." I had nowhere to go, all of the students had very different issues and it was impossible to find a place where we were 'allowed' to be. 
On another occasion I found myself alone with a very troubled student. Normally, we should not be alone with students, especially if they have been involved in family abuse. This student was a runner so I had to run after him out into the school yard. While I was chasing him through the school and out into the yard I called the office on my walkie talkie and no one answered. His emotional damage was far beyond my understanding, and the whole time I was alone with him I was furious that I was not being supported. I finally found refuge in an empty classroom where I could be relatively sure the student would be safe. The student busied himself by trying to fit a hamster into a very small compartment of a doll house. He had stolen the hamster from the classroom next door. I feared for the hamster, but positioned myself by the door to catch anyone passing by. I was feeling extremely uneasy about being alone with the student. The teacher, whose classroom we were in, arrived and I felt immense relief because I felt that I would be supported in my efforts to get this student back on track. I was taken by surprise when she became angry at me for allowing this particular student in her classroom. I was speechless. This was how some of the teachers reacted to having children with special needs in the school.

The perspectives of the EAs that I worked with were that there were no alternatives and that the problems faced were simply part of the territory. A saying that one co-worker shared with me comes to mind - "shut-up and wear beige". In other words keep quiet and blend in, don't make a fuss.

It did not make sense to me that the EAs were often not consulted when there were meetings with parents or the school psychologists. I felt uncomfortable when I realized I had been sitting at the wrong table in the staffroom. It was the teachers' table and we were not 
supposed to sit there. It was then that I felt that there was not a lot of value placed on the presence of an EA in the school.

I was left with the impression that the EAs did not have united voice - or any voice - and therefore, there were great discrepancies in the role from classroom to classroom. There was very little overt pride in the job and morale often dipped very low. One of my colleagues used to joke "you know, EAs just one up from pond scum". I often felt that the students were the only reason that many of my colleagues stayed with the job.

\section{Policy Context}

The employment of educational assistants (EAs) in the classroom has been a relatively recent phenomenon and occurred initially in response to a teacher shortage during the post World War II baby boom. Educational assistants were sometimes parents or grandparents of students within the school and had a great interest in the success of the school and community (Ashbaker \& Morgan, 2001). The school system offered low wages and frequently only part time positions, but the EA's presence in the school allowed them to be involved in the care and education of their children and the monetary compensation was deemed to be of secondary importance. Primarily women, educational assistants have now become a part of the school community by providing assistance with the delivery of programming to students with special learning needs (Ashbaker \& Morgan, 2001).

The policies written by the Ontario provincial government for the education programs of children with special needs are based on the assumption that open communication and collaboration within the school community should exist. Education for All (2005) outlines the Ministry of Education's recommendations for setting the tone of the professional relationship 
between the teacher and the 'support team' within the school community. The recommendations include: reflective teaching practices, appropriate planning strategies, favourable leadership qualities, which included collaboration and shared authority, and a positive teaching climate. The EA is not described as a part of the support team in Education for All (2005) and this absence is surprising in light of the role of EAs in supporting children with special needs.

It became the right of all children in Ontario over the age of five to have access to an appropriate, high quality, public education. In accordance with the requirements under the Education Act Regulation 181/98, no pupil is to be denied an education program. All the rules and regulations for the schools and the families are described in detail. The student's education program is required to be appropriate to the pupil's apparent strengths and needs as well as providing the necessary services to meet the student's needs (Ministry of Education, 2007). It is in this regulation that the identification, placement, and review committee (IPRC) process for children with special needs has been documented. The responsibilities of the school board, the principals, the teachers and the families are reviewed. There are no specific details on the way in which the student would be supported in the classroom. The role of the educational assistant is not defined at this level of the education system.

As the number of students with special learning needs in the general education classrooms grew so did the need for educational assistants (Ashbaker \& Morgan, 2001). Today, the numbers have grown to 619 educational assistants employed in the county being discussed and a total of 21,354 educational assistants employed in the province of Ontario (OPSEU Local 330). With the increase of EAs in the Ontario classrooms, many problems associated with this position have been identified, including lack of role clarity, feelings of low value among 
colleagues, lack of power over their own jobs, low compensation, low job satisfaction and low job retention. Educational assistants are expected to meet the physical, social, emotional and academic needs of the most vulnerable students in the school system with limited education and training (Giangreco, Edelman, Luiselli \& McFarland, 1997).

The enrolment of students with special needs entitled schools to hire additional EAs. Each student, depending on their needs had a certain number of hours of classroom support i.e., the number of hours increased with the severity of the student's needs. Ashbaker and Morgan (2001) suggested that with there were concerns about the increased responsibilities that the EAs had in the schools. They reported that EAs: were spending more time instructing individual students, they lacked formal training, were not included in the teaching team, did not receive school information or orientation and they often found themselves working in isolation without role models or feedback (Ashbaker \& Morgan, 2001).

\section{Gaps in Literature}

I also wondered what role the EAs would have in the transition away from segregation to a model where student with special needs are placed in the general education classrooms. It seems that our school board is moving away from segregated classrooms. There are indications that many school boards were also making this transition. There is a large body of literature based on the school system in the United States in which there are both segregated and inclusive classrooms. I found literature looking at the role of the educational assistant in terms of teacher appreciation, student interactions, job satisfaction and retention within the American education system (Ashbaker \& Morgan, 2001; Camahan, Williamson, Clarke \& Sorensen, 2009;

Giangreco, Edelman \& Broer, 2001; Giangreco, Edelman, Luiselli \& McFarland, 1997; Hughes 
\& Valle-Riestra, 2008, Minondo, Meyer \& Xin, 2001; Patterson, 2006). What I did not find was an analysis of the position of educational assistants as a part of the power hierarchy of the school. I felt that there would be value in studying the power relations as they existed in the public school boards by examining EA's perspectives on being an educational assistant in an Ontario classroom. I wanted to know how they viewed their jobs, how they were treated by principals, teachers and co-workers, and where they fit in the general and segregated classrooms. I wanted to examine if there were valid reasons for some of the problems we were facing as EAs in this province. I felt that if I could link the issues raised in my small sampling with those presented in the existing research found in the United States my findings would be a valuable addition to the body of current literature.

The existing body of research has been valuable. The current research is evidence that the investigation into the complex nature of the educational assistant's role has begun. One of the critical gaps in the current literature is the lack of Canadian content. Much of the research has been conducted in the United States, where education system is controlled at the federal level and in Canada the education system is wholly a provincial responsibility. A Canadian focus would help to examine the role of the educational assistant in Ontario and to highlight similarities and differences between Canada and the United States. Another gap in the current body of research are the explicit perspectives of the educational assistant. There appeared to be a lack of literature dealing with the position of the EA with a focus on their knowledge of the union's role in the education system. Additional research which focuses on the relationships that EAs have with the school boards, unions, principals, teachers and one another may provide insight into the factors which influence the perspectives of the EAs on their role in the classrooms. In doing so, we may find some of the major influences that are responsible for the 
challenges met by EAs in the classrooms. This study will examine the educational assistant's perspectives on being an EA in an Ontario classroom.

\section{Theoretical and Contextual Framework}

To explore the perspectives on being an EA in an Ontario classroom I have chosen Friere's theory and critique of the education system for three reasons. First, he has described school structure as hierarchal. He has stated, “...this whole issue of teaching and educating is a basic one...clearly defined political positions in a hierarchal world, in which those who possess power possess knowledge" (Friere, 1989, p. 34). Second, through a hierarchal system some groups have power and some are marginalized. The relationship between those with power and those without is constructed by society and internalized creating the guidelines for the behaviour of both the oppressor and the oppressed. "One of the basic elements of the relationship between the oppressor and the oppressed is prescription. Every prescription represents the imposition of one individual's choice upon another, transforming the consciousness of the person prescribed to into one that conforms with the prescriber's consciousness. Thus creating the behaviour of the oppressed is a prescribed behaviour..." (Friere \& Macedo, 1998, p. 48). Third, according to Friere (1989), the authoritarianism, which is present in the hierarchal education system, does not allow for our 'capacity for asking questions.' To ask questions is considered an attack on authority (p. 35). "I would like to stress that the source of knowledge lies in inquiry, in questions, or in the very act of asking questions" (Friere, 1989 p. 37). Friere has said, you should ask questions, but some may just want conformity. Power may not be what the marginalized group really desire. "They prefer the security of conformity with their state of unfreedom to the creative communion produced by freedom or even the very pursuit of freedom." (Freire \& Macedo, 1998 
p. 49). Friere's critique of the education system will assist me in my analysis of the position of the EAs as part of the hierarchal system of the school.

\section{Literature Review}

It is the right of every child to receive a high quality education. Those involved in the education system must be clear about the best delivery of that education. The following review of the current literature examines some of the challenges faced by the educational assistants.

\section{Perspectives on Role Clarity, Job Satisfaction and Job Retention}

Researchers have suggested that as the classroom became a more diverse learning environment, the roles became less clear for the adults who are teaching the children. The apparent lack of clarity in the responsibilities and direction of the educational assistants in the classroom was found to result in negative experiences for the EA and the student with disabilities. Giangreco, Edelman, Luiselli and McFarland (1997) found that there was an absence of role clarity for the EAs, which resulted in negative perceptions of the value added by an EA in the classroom. Their results indicated that if the EA did not have a clear idea of what the assigned tasks of the job were, then the EA would tend to stay physically close to the student with disabilities. The closeness of the adult to the student may cause a reduction of the student's interactions with peers, as well as create dependency issues (Giangreco et al., 1997).

In observations by Takala (2007) it was found that EAs who were assigned to younger students tend to be busier. The lack of training did not seem as apparent, as the needs of the 
younger student were greater and the EA was expected to perform tasks to ensure the health and safety of the young students. As the students became older and their needs were fewer the EA had more idle time which, according to Takala (2007), was time the EA could spend assisting the teacher. Takala (2007) suggested that in order for the EA to be of assistance, the teacher would have to direct the EA in ways which would help the progress of the lessons being taught. If the classroom were to run efficiently, both the teacher and the EA would have to be willing to collaborate and spend time planning before the lesson. Takala's (2007) finding was that teachers did not necessarily assume that this was part of their job.

Bourke (2009) suggested that the EA does not receive sufficient training, guidance or ${ }^{\circ}$ background information on the student they were assigned to support. On-the-job training often consisted of shadowing another EA or listening to the lesson and waiting for the teacher's instruction.

Patterson (2006) reported that the EAs felt great frustration at changes made to the daily schedule by the teachers or the principals as these last minute changes made it difficult for the EA and the student to know what any given day would hold. The educational assistants in the study felt that if their roles were more clearly defined, everyone would know what their responsibilities were and the expectations of what they are able to achieve on a daily basis would be more realistic. These factors all contribute to low job satisfaction for the EAs (Patterson, 2006).

In a study conducted by Hughes and Valle-Riestra (2008), involving 52 EAs and 59 teachers, there was concern that EAs were being asked to do too much of the teacher's job when working with certain students. They felt they were doing the teacher's job without financial 
compensation. The EAs were not blaming the teachers, but were looking to the administrators who may be in a better position to make changes to their assigned duties (Hughes \& ValleRiestra, 2008). Some educational assistants felt that they were doing much of the same work as the teachers, but because they did not have a teaching certificate they did not receive the same compensation and often had to take a second job. This had a negative effect on job retention (Hughes \& Valle-Riestra, 2008).

Patterson (2006) argued that what the EA was required to do in the classroom often was very different from what they felt they were qualified and paid to do. In some schools an EA would have a small group of students or would teach the large group. There was a mixed response to this, with some enjoying the added responsibility and others resenting the expectation that they would do the teacher's job without compensation and sometimes without clear instructions. Behaviour management was also an expectation. It was often expected that the EA would deal with behaviour regardless of who was responsible for the student. This could also have a negative impact on job satisfaction, leading to low job retention (Patterson, 2006).

According to Giangreco et al. (1997, p.12), teachers felt that if the educational assistants were utilized specifically as a support and not as the primary educator, it would benefit the student. Often the students with disabilities had the most complex learning needs and should not be taught by the least trained adult. The purpose of this study was to help teachers understand the valuable resource found within the educational assistant. Teachers must also be aware of the potential danger of relying on an untrained support worker to perform the duties of a certified teacher (Giangreco et al., 1997). 
In a perfect school system, according to Carnahan, Williamson, Clarke and Sorenson (2009), teachers would have insight into some of their responsibilities for training, supervising and educating other adults. They ranked open communication, a shared philosophy and respect as high priority items for a positive relationship between the teacher and the EA. Carnahan et al. (2009), recommended that educational assistants should be part of the teaching team. There should be consistent and predictable behaviour from the adults and the focus should be on the students, not on the interactions of the adults (Carnahan et al., 2009). Hughes \& Valle-Riestra (2008) pointed out that the school system was far from being perfect and both the existing teachers and the new teachers must be prepared to supervise another adult in the classroom whether they have training or not. This was difficult for a new teacher trying to understand how to teach the children effectively and at the same time understand the importance of collaborating with the EA.

The existing research according to a review by Bourke (2009) indicated that the role of the educational assistant remained undefined and unclear. The study revealed that issues of powerlessness, lack of identity, low salaries, and lack of support were all part of the low opinion educational assistants had of themselves and of the job that they do. These perceptions had manifested in low job satisfaction and low job retention (Bourke, 2009). Bourke (2009) also noted that exploring this area of research and conducting further research in this area would encourage the schools and staff to take a closer look at the role of the educational assistant. By examining the current literature the teachers and administrators would come to their own conclusions and recognize the value of the educational assistants and their potential contributions in an inclusive classroom (Bourke, 2009; Giangreco et al., 1997). 
Giangreco, Edlelman, and Broer (2001) felt that respect, appreciation and acknowledgement of an educational assistant had an effect on morale. Their findings suggest that the EA had a strong desire to be included and to have a voice on the education team. The research found that there were discrepancies between individual cases in terms of expectations, role clarity, and monetary compensation, all of which were considered indicators of respect and appreciation and should reflect the level of responsibility, if there were going to be greater job satisfaction and greater job retention.

\section{Bane or Blessing: The Educational Assistant in the Classroom}

Giangreco, et.al (2001) found that the level of engagement the teacher had with a student with special needs increased and decreased depending on how the educational assistant was assigned. There were two possibilities: the EA could be assigned one-on-one with a disabled student or the assignment could be to support the class and all of the diverse learning needs, both possibilities were found in the job description for Simcoe County District School Board (see Appendix A). The level of teacher engagement was found to decrease if the EA was assigned to one student. This put the educational assistant in a difficult position. The EA was often left to work with the student alone, possibly without instruction from the teacher. In earlier research, Giangreco et al. (1997) also found that if the educational assistant was assigned to only one student, often that student experienced isolation from the rest of the class because a stigma was attached to always having an adult at your side and dependencies were often created (Giangreco, et al., 1997).

Research indicated that the contribution of added support, by an EA, could be a positive and valuable resource for all students and classroom teachers. Everyone could benefit if the 
assistant was placed in the classroom to support all of the students and to assist the teacher delivering the curriculum, though it would necessitate teamwork and collaboration between the adults in the classroom. Cremin, Thomas and Vincett (2003) reported on a study conducted by the Centre for Inclusive and Special Needs Research. The educational assistants were given specific tasks to perform and in each classroom the EA's tasks were slightly different. The study provided feedback which indicated that there were improvements in student engagement no matter how the EA was assigned (Cremin et al., 2003). If student engagement improved using both models, then it stands to reason that clearly defined roles educational assistants will become a much more efficient and valuable resource to the classroom (Bourke, 2009; Giangreco et al., 1997; Takala, 2007). Cremin et al. (2003) suggested that there was a need to learn how to assign an EA to a classroom according to the individual needs of the students in that classroom. The results of this study reinforced the idea that there was a lack of training and knowledge of teachers and assistants working together as a team. There seems to be a trend in the research (Bourke, 2009; Carnahan et al., 2009; Giangreco et al., 1997; Hughes \& Valle-Riestra, 2008; Takala, 2007) indicating that if teachers collaborated with educational assistants, then the general education classroom would run more efficiently and the students would be taught in a more effective manner.

Marks, Schrader and Levine (1999) conducted a study which involved 25 educational assistants. Interviews established their typical daily routine and the tasks they were asked to perform. The researchers suggested that the reason EAs work in an isolated environment may be systemic. They suggested that the EA did not want to bother the teacher and wanted to make their presence a positive experience in order for the teacher to be more accepting of the student with special needs. They found that EAs looked upon their ability to cope, deal with disruptive 
behaviours and maintain a positive relationship with the teacher, as a reflection of their job performance. Often it was not possible to wait for the teacher to provide instruction or modifications for the student under their care and the EA quickly became the expert on the needs of the student. EAs felt that they should have input and communicate their knowledge to the teachers and parents. They were in an advocacy position where the student's place in the general education classroom was on the line. They needed to represent the student in a way which would gain acceptance (Marks, Schrader\& Levine, 1999).

Minondo, Meyer and Xin (2001) explored the benefit of having an EA not only supporting a classroom, but also providing regular communication with families. With their knowledge of the student and appropriate training and supervision it was felt that the EA could be a good source of support for the families. There was a need for a liaison between home and school. Horne and Timmons (2009) indicated that the knowledge that the EA had of the student and the family added another support for the teachers to draw on and create curriculum.

The voice of the student and family was heard through the EA. Both Giangreco et al. (2007) and Horne and Timmons (2009) felt in addition to the family as a support and resource teachers are also able to draw upon the EAs for support. "Teachers and educational assistants working together as a team will allow the creation of a positive inclusive classroom culture, acknowledgement of differences, acceptance of students and students working together to solve real life problems" (Giangreco et al., 2007, p. 37).

\section{EAs in the General Education Classroom}

Educational assistants are present in both segregated and general education classrooms and are assigned to support students with special needs. Researchers are not in agreement on the 
most effective way to create an inclusive environment, within the general education classroom for students with disabilities as well as typical students (Bourke, 2009; Carnahan et al., 2009; Giangreco et al., 1997; Hughes \& Valle-Riestra, 2008; Takala, 2007; Zigmond, 2003). There is concern over whether it is even possible to truly achieve an inclusive classroom using our existing education system (Slee, 2001; Sikes, Lawson \& Parker., 2007).

The education system in Ontario is working toward including students with special needs in general education classrooms, but many segregated classrooms still exist. Until there is a clear understanding of how to include students with special needs in the general education classroom, the roles and responsibilities of the EAs will not be clearly understood (Sikes, Lawson \& Parker., 2007). The way society views disability will continue to influence the way children with special needs are treated in the school system (Slee, 2001). Success for students with special needs requires an intense commitment from school leaders, teachers, EAs, parents and students all working collaboratively toward a classroom where all students are receiving an appropriate education (Bourke, 2009; Carnahan et al., 2009; Cremin et al., 2003; Giangreco et al., 1997; Hughes \& Valle-Riestra, 2008; Takala, 2007).

\section{Summary}

Questions about the role of the educational assistant have created debates about whether their presence in a classroom nurtures or stunts the intellectual and social growth of the students with special needs (Giangreco et al., 1997). The literature presented in this paper has indicated that there are negative and positive effects, on both the teacher and the students, of having an educational assistant in the classroom. The literature clearly stated that there was also controversy surrounding how to include students with special needs in the general education 
classroom. This presents an added difficulty for teachers: if they were not clear about how their inclusive classroom should look, would they be able to guide an EA and clearly define their role? With the steady enrolment of students with special needs into the general education classrooms, it would be wise for researchers to explore some viable solutions to the controversy surrounding the utilization of the EA as a support for students with special needs.

This qualitative study explores the perspectives of the EA working in the classroom, by listening to their stories. It examines the experiences of educational assistants working, in a small community, in Southern Ontario, about sixty kilometres north of Toronto. This small scale study focuses on the experiences of five educational assistants from two different schools, who are currently working with students with special needs in both segregated and general education classrooms. The purpose of the study is not to generalize but to gain insight into specific and individual experiences of a small number of participants. I strive to explore the existing experiences and look at recurring issues faced by EAs in Ontario classrooms.

\section{Research Questions}

What are the perspectives on being an EA in an Ontario classroom?

In what ways do EAs explain their roles and responsibilities in relation to school board policy?

How do the perspectives of the EA compare to the official job fact sheet which was created as part of the collective agreement between the school board and OPSEU?

How do EAs consider their roles in relation to that of the teacher's?

How do EAs consider their roles in relation to that of the principal's? 


\section{CHAPTER II}

\section{Method}

\section{Research Design}

A qualitative approach was chosen to explore and understand the research questions through the experiences of the participants.

Two methods of data collection were used. Journals were kept by the participants and one-on-one interviews were conducted. Journals were the first stage of data collection. The participants were able to express their feelings in a thoughtful, timely manner. The interview process was chosen to provide the researcher with information which added depth to the ideas presented in the journals. A qualitative approach allowed me to hear the stories, opinions and feelings of the participants.

Themes, or recurring ideas and pattems emerged from the data which allowed me to gain deeper understanding of the working conditions of the EA. Grounded theory is a qualitative strategy used to create or develop theories which were found within the experiences of the participants (Creswell, 2009). A grounded theory approach allowed deep insight into the relationship between the working conditions of the EA and their perspective on working in an Ontario classroom. The process of grounded theory involves multiple stages of data collection, which were be examined to determine the relationships between categories extracted from the data (Creswell, 2009). The theory evolves from the participant data and from the voice of each participant. The ideas are reduced to more general terms which allow a theory to be developed to explain the perspectives of the EAs on their place in the classroom (Strauss \& Corbin, 1998). 


\section{Minimizing Risk for Participants}

For the purpose of this study the participants were not asked to discuss specific students and pseudonyms were used to keep their identity confidential. The participants were made aware that they did not have to answer any questions deemed offensive or inappropriate and were aware that they could withdraw at any time during the study, after which their data would be destroyed (see Appendix B for consent form).

My knowledge of the participants and of their workplace posed a potential social risk to their place in the community and at their job. The description of the study outlined the data collection methods in the form of written journals and one-on-one interviews. The journals and the interview transcripts remained confidential. Access was only granted to the research supervisor and me, the researcher. The consent form was signed by the participants, which outlined all measures taken to minimize these potential risks. The proposal for the research study was approved by the research ethics board at Ryerson University. I assured the participants of the measures I was taking to maintain confidentiality. The written journals were kept in a locked file cabinet. The audio tapes were copied to $\mathrm{CD}$ and transcribed by myself and all audio material was also kept in the locked cabinet. The material will be kept for seven years.

\section{Recruitment}

Purposeful sampling was used for this study. These participants were chosen from a small group to provide me with greater understanding of the research questions (Creswell, 2009). To ensure rich and relevant data the five educational assistants were chosen because of their professional background. The participants spent time working in either inclusive or segregated settings or both. Further, they had worked in elementary as well as secondary schools, which 
provided this study with a wide range of experiences. All but one participant had spent time working in the elementary grades and two of the participants had experience in both elementary and high schools. There are slight differences in the allocation of EAs between the elementary and high schools because of the difference in scheduling between the two levels of schools. In the high schools there are usually a greater number of special education resource teachers (SERT) as well as a head teacher responsible for the coordination of all of the EAs and the SERTs. Although these differences are present between the two levels, the job fact sheet did not make the distinction between elementary and secondary schools. For the purposes of this study there was no distinction made between the elementary EAs and the secondary EAs. All participants were currently employed as educational assistants in the Ontario public school system.

The recruitment process took place over the telephone. Each participant was contacted individually, and using a script (see Appendix C for script), the study was explained and they were given the opportunity to accept or decline. The first five participants accepted and none declined. Due to time limitations I recruited the first five participants that accepted. Two of the participants worked together as a team in the same classroom. They accepted the request to be involved in the research, but informed me that they would like to be interviewed together. It was an interesting dynamic, but one that proved to be more of a limitation than a strength. One participant was more inclined to answer the questions and I could not be sure they were answering the questions using their own beliefs and values. All of the participants were known to me. The community where the research study was conducted and where I have worked as an EA is small and for this reason, I consider myself to be an insider. As the researcher, $I$ had to ensure that my bias was always taken into consideration. I took measures to minimize this bias. I was no 
longer employed as an EA, I kept all interactions with the participants confidential and I discussed my own experience as an EA. My experience did however, provide me with insight and background into the job of the EA, which I may not have had due to limitations such as lack of time and the inability to observe classrooms.

\section{Participant Profile}

Alice. Alice has been an educational assistant for seven years. Her educational background was in nursing, but she later returned to college and earned her developmental service worker diploma. She began to see signs of learning difficulties in her own children as they grew and made their way through the school system. It was at this point she realized the resources available to assist her children in school were very limited, so she decided to become an EA. This allowed her the ability to earn an income, be involved in her own children's school experience and keep the same schedule as her family. Alice has had experience in both elementary and secondary schools. In the elementary schools she worked with children between the ages of five and thirteen. In the secondary schools she has worked with students between the ages of fourteen and twenty-one.

Brenda. Brenda has been an EA for nineteen years. She has her high school diploma. She had applied to the school board to work in the office as a school secretary. Her children's school was in need of supply EAs. She was becoming more available as her children began full time school, so she agreed to fill in once in a while. When a position became available she applied and thought she would try it for a short while and she ended up staying. She has only worked in the elementary schools with children ages five to thirteen. 
Carol. Carol has been an EA for twenty years. She began her employment with her high school diploma and later returned to earn her educational support worker diploma. This was difficult for her because her children were small at the time, but the school board informed her that she needed to upgrade. Before Carol became an EA she was a-stay-at home mother and she frequently volunteered at the school. Eventually the principal offered her a job. She was not at all sure that she wanted to go back to work, but she tried the job and enjoyed the convenience of having the same schedule as her children. Carol also spent her years on the job in the elementary schools working with children between the ages of five and thirteen.

Donna. Donna has been an EA for eleven years. Her background was as a legal clerk. Donna was very involved in the school council at her son's school. The principal approached her and offered her a six week job as an EA. The school was desperate and they had just received funding for the position. The job was only supposed to be temporary, but she stayed on. When the policy regarding qualifications was implemented, Donna had been there long enough that they 'grandfathered' her position and she was able to stay without upgrading. This job came to Donna when her children were attending the local high school. She gained enough seniority that she has never been asked to take a position at another school. All of her experience has been working with children between the ages of fourteen and twenty-one.

Eve. Eve had a background in early childhood education. She began her career in the childcare field and found herself working with the children with special needs. It eventually led to the job with the school board. She liked to work with children with special needs and she was able to keep the same hours as her children. She has been an EA for six years. Up until two years ago Eve had only worked with children in elementary schools, ages five to thirteen. When the 
school board was making staffing changes she accepted a position at the high school, where she now works with students fourteen to twenty-one. The lack of cultural and gender diversity in the sample of participants may be a limitation.

The participants were women who had children of their own in the school system. They were all drawn to the convenience of having the same schedule as their children and in some respects the low wages seemed to be secondary in importance. The participants' experience varied with the age of the children they worked with.

Although elementary and secondary schools differ in terms of curriculum, schedules and staffing structure, the job of the EA as described in the Job Fact Sheet does not make the distinction between elementary and secondary. Two of the five participants had prior experience with children with special needs. The average number of years on the job was 12.7 years. All participants held a college diploma, with the exception of two.

According to the Non-Teaching seniority report for OPSEU (The Ontario Public Service Employees Union) Local 330, as of January 31, 2010, 15\% of EAs in this school board do not have post secondary education. The remaining $85 \%$ have a college diploma or university degree. Two of the five participants fell into the first category and the other three have college diplomas. The EAs who are not qualified have been 'grandfathered' in by the school board. The school board provides special training workshops and courses throughout the year. Some are held on professional development days and others are after hours on the EAs own time. All courses offered by the school board are of no cost to the EA. 
Table 1

Summary of Participant Profiles

\begin{tabular}{|c|c|c|c|}
\hline Name (pseudonym) & Job title & Education & Years on the job \\
\hline Alice & Educational assistant & $\begin{array}{l}\text { RPN-registered } \\
\text { practical nurse. } \\
\text { DSW-developmental } \\
\text { servicer worker }\end{array}$ & 7 years \\
\hline Brenda & Educational assistant & High school diploma & 19 years \\
\hline Carol & Educational assistant & $\begin{array}{l}\text { High school diploma, } \\
\text { ESW-education } \\
\text { service worker }\end{array}$ & 20 years \\
\hline Donna & Educational assistant & Law clerk & 11 years \\
\hline Eve & Educational assistant & $\begin{array}{l}\text { ECE-early childhood } \\
\text { educator }\end{array}$ & 6.5 years \\
\hline
\end{tabular}

\section{Data Collection}

Each participant was asked to keep a journal for three to five days. A written journal would provide a sample of the participant's thoughts and ideas. The participants took time to reflect on their feelings in an unobtrusive manner (Creswell, 2009). They were able to organize their thoughts without the pressure of having to immediately answer a question during an interview. The journals were an introduction to the issues and concerns that the participants felt 
were critical to discuss in their interviews and proved to be instrumental in adding depth to the interview process. The participants were asked to describe the following in their journal entries: the tasks they were assigned and who assigned it, whether they felt the assigned task was within their job description, and to reflect on their feelings about their day. There was a wide range of responses in the journal entries. The participants wrote entries for as few as two days and for as many as five. The length of the entries varied between two and thirteen pages, with an average length of nine pages. Some of the entries were an hour by hour tracking of their day, and some participants chose to focus on the reflective aspect of the journal writing. From both the detailed descriptions of the EA's tasks and from the reflection of their own feelings, I was able to extract some common ideas and feelings which would be reflected in the interview questions. The common ideas taken from the journal entries were: duties, communication, change, teacher-EA interactions, training and appreciation.

During the interviews I was able to fill in the background of each participant, direct the line of questioning which led to the relevant information and be informed of the classroom dynamics that I was unable to observe first hand. The interview questions acted as a guide for the interviewer (see Appendix D for interview questions). Some of the questions were added to address the participant's ideas as outlined in their written journals. Questions pertaining to schedule changes and type of support they would like to have in their job were added. The other questions were expanded as necessary, to ensure all of the ideas were discussed.

During the interview the participant discussed issues raised in the questions such as their feelings about their job and responsibilities, their relationship with the teachers and principals, communication at all levels, their knowledge of education policy and education or training. I 
wanted to examine where the EA was situated within the structured relationships in the schools. The goal was to capture the thoughts of the EAs and address this study's research questions through the interview process. It was important for me to have the participants explain to me in their own words what their perspectives were on their role in the segregated or general education classroom.

The participants were interviewed individually on different days except for Brenda and Carol who insisted on being interviewed as a team because that was how they worked in the classroom. Each interview took place at a quiet coffee shop where the participants felt comfortable except for one participant who wished to be interviewed in her own home. All interviews were audio taped and transcribed as stated in the consent form, which was signed by all participants. Each participant was given a copy of their transcribed interview to review and revise if necessary. Participants were consulted when clarification was necessary.

\section{Data Analysis}

Following the basic coding methods, as discussed by Strauss and Corbin (1998), I was able to identify the phenomena which were the central ideas in the data. These central ideas are represented as concepts. The concepts that emerged from the participant's journals were then pursued during the interview process to form the categories. Four of the five participants discussed the issue of communication in their written journal. For example, Donna discussed in her journal the issue of not being invited to meetings, therefore the question was asked, "Do you ever go to staff meetings, and if so do you have a voice there?" 
Memos were kept during the open coding process in order to clarify the intended characteristics of the category. For example, during the interview Alice used the term "clarification" when describing how she dealt with a situation where she was not comfortable with the supervision at lunchtime. I noted in the margin that "perhaps the participant really wanted to let the teacher know she was not happy with the situation, but did not clearly say so. Is this an issue of communication and not feeling as though you have a right to voice concern?" I followed up with the participant to verify the meaning of the statement and I was able to put this statement into the proper category.

The comparison and categorizing of data from each participant led to the creation of subcategories to further clarify the main ideas and characteristics of the categories. Using the memos and referring back to the research questions the data was grouped into categories and subcategories exemplifying the concepts which would eventually become the building blocks of the theory (Strauss \& Corbin, 1998).

\section{Open Coding}

"Open coding is the analytic process through which concepts are identified and their properties and dimensions are discovered in the data." (Strauss \& Corbin, 1998 p. 101) Open coding was used to identify the phenomena which emerged from the data and were represented by concepts and were then put into categories. Further analysis of the category allowed subcategories to be formed, which gave definition and meaning to each category. The journals were reviewed entry by entry prior to the interviews. From each journal I was able to determine common thoughts and ideas held by the participants. These ideas were used to guide the interview questions, which allowed me to be certain that the EAs focused on their primary 
concerns. Next the data were systematically reviewed and categories were created according to the similar characteristics found in each journal and interview. Participants were consulted for clarification on various points. The interviews were transcribed, and each line was numbered. For each participant I went through the transcription line by line and made a note in a notebook indicating the general idea of each line. For example, line 111 from Donna's interview "So a teacher goes to a SERT (special education resource teacher), and says 'here's what is going on' and goes to the meeting, so the teacher is at the meeting but not the EA" was put under the subcategory of "broken telephone". Using the general ideas written in the notebook I was able to create, on chart paper, large visuals indicating categories with corresponding line numbers for each participant. From the large chart paper I was able to identify the concepts and create the major categories.

The major categories which emerged during the open coding stage were: 1) roles and responsibilities, 2) relationships (students, teachers and principals), 3) communication (school board, union, principals, teachers, and parents), 4) changes (inclusion, schedule changes, importance of flexibility), and 5) education or training. For each category listed there were supporting subcategories. I continued to compare, trying to find relationships between the categories and looking for patterns in the data.

In this phase of the analysis I started to become aware of the strong patterns emerging from the journal entries and my interviews with the participants. There were many factors which influenced the perspectives of the EAs on their roles and responsibilities, but I felt that with further analysis the data would show whether the subcategories would collapse to reveal the categories which were closer to the root of the EAs issues. 


\section{Axial Coding}

Axial coding is "the process of relating categories to their subcategories, termed 'axial' because coding occurs around the axis of a category, linking categories at the level of properties and dimensions" (Strauss \& Corbin, 1998 p.123), which are the characteristics which define and give meaning to a category. During this phase of the data analysis I determined that the subcategories of the five main categories were interrelated to both the category of relationships and communication. Relationships and communication were identified as the two central themes. The other categories were identified to show their interrelationships to the central themes and further examine the complex nature of the educational assistant's workplace. This was achieved by gathering data from each participant's transcribed interview. The thoughts and experiences from each interview were organized into the six main categories. As previously stated, it became evident that the main categories were interrelated and could be collapsed into two major themes. For example, aspects of the category of training, roles and responsibilities and changes were related to the discussion about relationships and other aspects of the category of change, training and roles and responsibility were related to the issue of communication.

\section{Selective Coding}

Selective coding is, "the process of integrating and refining the theory."(Strauss \& Corbin, 1998 p.143) In the last stage, which is selective coding, the theory is refined and the subcategories are organized in the context of the central categories. According to Strauss and Corbin (1998), categories and subcategories are constructed from the data by the researcher. The researcher reduces the data from many cases into categories and subcategories, where the subcategories define and give meaning to the categories. The relationship between the categories 
and the subcategories can then be used to explain in a general sense what is going on. During this final step I created a chart to provide a visual display of the categories, subcategories and relationships. Using the categories as the headings I examined the interrelationships between the subcategories and was able to collapse the categories to two central categories. By arriving at two central categories, it became clear that many of the factors which influenced the perspectives of the EAs on their roles and responsibilities were grounded in the relationships they had at school with teachers and principals, as well as the level of communication they achieved while working in the schools. I continuously returned to the data to recheck changing themes and categories. Constant comparisons also forced me to acknowledge my own biases, assumptions and also those of the participants.

\section{Credibility, Authenticity and Trustworthiness}

Member checking was used to ensure credibility, authenticity and trustworthiness. I clarified the meaning of the participant data at various stages of the research project. Constant comparison of data between participants ensured that the interrelationships between categories and subcategories were identified and noted. The full and detailed description of the participant's experience added clarity and meaning to the interpretation which was presented in the discussion. I provided self-reflection and honestly stated any bias which I brought to the research. Prolonged time in the field lends credibility. I have spent time working in the field and was able to use my knowledge and understanding of the challenges facing the participants to add depth to the discussion (Creswell, 2009). 


\section{CHAPTER III}

\section{Findings}

The core categories and the supporting subcategories have been the basis for developing a general theory. This theory explains the factors which influence the perspectives of educational assistants on being an EA in the Ontario classrooms. The major categories were identified: 1) roles and responsibilities, 2) relationships, 3) communication, 4) changes, and 5) training. The interrelationships between these categories highlight the complex nature of the role of the educational assistant.

\section{Major Categories}

Roles and responsibilities. The findings indicated the diverse nature of the EA's daily responsibilities. The EA was required to understand how to support all of the varied needs in the classroom, while also having the specialized training to attend to their varying medical and physical needs. The teacher gave the EAs direction, but in many cases the EAs learned on-thejob and were trained by other EAs. Often when the students were not in immediate need, the EAs were requested to look after light administrative and organizational tasks. On occasion the segregated students and their EAs were given activities, such as school yard clean up.

The daily tasks differed slightly depending on what the needs of the students were. Some of the students needed academic support, emotional, social and others needed complete physical assistance. The descriptions of the daily tasks were also discussed in the interview, which served as a follow up to the journal entries. The participants are quoted from the interview transcripts, unless otherwise stated. 
Alice is an EA who works in both inclusive as well as segregated classrooms. She described the wide range of duties she may encounter in a day,

...giving them their support that way, sometimes by computer, sometimes by reading, sometimes by scribing... but in the life skills setting you are dealing with a whole gamut of different things, you are dealing with toileting, with students -you are not always with the same student so you have to know all of the idiosyncrasies of all of the students, what their needs are, what the safety plans are.

Donna was in charge of a special lunch program at her school. It was a time for her to touch base with the students and eat lunch with them. In a natural way she was teaching them social skills, but it was often on her own lunch hour. Donna explained,

So basically I had five autistics everyday that came in and worked on the computer. I was also available for any other kid who wanted to come and work on the computer it was fine they were welcome to come in if they wanted help with quiet study work or help with essays. I also would do that, lots of projects at lunch.

Alice reported on the wide spectrum of special needs, with which an EA must be familiar. So...medically fragile student, so dealing with her needs and lifting and feeding, cause well actually she is doing better with assisting eating and actually today the spoon was on the table and she reached for it. So she has come a long way. Then you have students with autism, so you can have severe to mild. Students with Aspergers and students who are just $\mathrm{LD}$ [learning disabled] and then you have other students who are not identified so technically you are there to support them too, unofficially, because you will notice that they need help. 
The other tasks that EAs are asked to do generally fall into the category of administrative or cleanup. Alice gave an example, "there was just the odd time like when... I was in resources it seemed like it was more secretarial." Brenda and Carol commented on the frequent cleanup tasks the students in the segregated classes have to do, "we were cleaning up all of the pinecones out in the yard into big garbage cans and we had to carry them around and put them in the dumpster" Alice discussed the need to know the students in order to manage their behaviour in class, As I got to know some of the students I knew what the best way in order to direct them or to get them to focus or you know do you use humour with some, do you go over and tell them Ok this is what I need you to work on, do you understand, what do you need help with, ok let's start with this just brainstorming some ideas.

Table 2, summarizes some of the duties assigned to the participants. A description is provided of the task and how it is performed by the EA. The participants suggested ways in which they could be supported in their roles and responsibilities. 
Table 2

Summary of EA's Roles and Responsibilities

\begin{tabular}{|c|c|c|}
\hline $\begin{array}{l}\text { What do the EAs say they } \\
\text { do? }\end{array}$ & How do they do it? & $\begin{array}{l}\text { In the eyes of the EA how } \\
\text { could they be better } \\
\text { supported? }\end{array}$ \\
\hline $\begin{array}{l}\text { Support academics in the } \\
\text { classroom }\end{array}$ & $\begin{array}{l}\text { Work } 1: 1 \text { with students, } \\
\text { Float in classroom and support } \\
\text { others, } \\
\text { Adapting lessons as the } \\
\text { teacher gives the lesson }\end{array}$ & $\begin{array}{l}\text { Planned preparation of lessons } \\
\text { with teacher }\end{array}$ \\
\hline Teach social skills & $\begin{array}{l}\text { Spends lunch hour eating with } \\
\text { the students, sometimes on } \\
\text { own time }\end{array}$ & $\begin{array}{l}\text { Support from department to } \\
\text { implement this important } \\
\text { program }\end{array}$ \\
\hline $\begin{array}{l}\text { Take care of the physical } \\
\text { needs of the students }\end{array}$ & $\begin{array}{l}\text { As needed, } \\
\text { Know safety plans for student } \\
\text { medical emergencies }\end{array}$ & $\begin{array}{l}\text { Specialized training and full } \\
\text { knowledge of student's needs }\end{array}$ \\
\hline "other" duties & $\begin{array}{l}\text { Are asked to do tasks around } \\
\text { the school with their students } \\
\text { i.e., cleaning up the school } \\
\text { yard, } \\
\text { Office tasks i.e., filing and } \\
\text { organizing }\end{array}$ & $\begin{array}{l}\text { Include all the students in } \\
\text { these projects, not just the } \\
\text { students with special needs, } \\
\text { Complete organizational tasks } \\
\text { when students are not there }\end{array}$ \\
\hline $\begin{array}{l}\text { Monitor and manage student } \\
\text { behaviour }\end{array}$ & $\begin{array}{l}\text { Watch for signs and triggers } \\
\text { that may affect the student's } \\
\text { behaviour, redirect, have pre } \\
\text { determined strategies that both } \\
\text { the EA and the student know }\end{array}$ & $\begin{array}{l}\text { Special training, time to meet } \\
\text { with the students and the } \\
\text { teacher to ensure all parties } \\
\text { understand the situation }\end{array}$ \\
\hline
\end{tabular}


Relationships. The participants discussed the different relationships that existed in the school community. Relationships between EAs and principals, EAs and teachers, and other EAs were discussed. The journal entries suggested that there were some challenges for the EAs in the area of their work relationships. During the interviews I was able to ask the participants about their perspectives on dynamics between the different groups within the school. The findings suggested that all of the participants felt that they were not a valued partner in these relationships and that they felt that in many cases it was best to not ask questions. The participants reported that, although it was their responsibility to provide support to the students they were not expected to question the decisions made about the delivery of the support. This made the relationships very one-sided. On the other hand the lack of knowledge also absolved the EA of any responsibility.

Ours is not to reason why. Alice reported that she felt that even though she was a lesser partner of these relationships she wasn't privy to the necessary information. She admitted that she had questions for the teacher and the principal, but felt that she wasn't informed enough to ask. She did not understand the reason behind a decision which was made about a student.

I just might question it because I may not understand the way that the decision has been made, but ultimately it is not really my responsibility to question because there is a bigger picture than what I see. There may be other dynamics that I am unaware of.

Brenda and Carol work together as a team. They reported that they support each other, but explained that in order to make their day run smoothly they do not bother the teacher or question his requests. Carol made the comment that, "I just do what the teacher wants... I just believe in just doing what the teacher wants." 
Donna made the observation in her journal that as an EA she was not included in parent meetings or in the decision making process with the teachers and she commented on the general impression "that we are just EAs one above sludge."

The participants agreed that there were consequences to speaking up and voicing their concerns to the teachers and the principals. Carol stated, "no and I don't think I would say anything to her because I think it would just create a problem, you know?"

Brenda went on to comment,

I don't feel as though we could go in there and air our feelings about it and just being in the school environment you just don't do that, they just aren't trained to do that. If I was having problems with someone that I worked with they would basically say to me well too bad like it or lump it.

Brenda and Carol were commenting on the fact that they did not feel as though there were any solutions to the concerns they had at their school. They felt that anyone in a position of authority would label them as disruptive if they spoke up.

Well, unless we start marching and we go in there and make a fuss, but they don't have time for that. Like that kind of, if we made a stand we would be causing problems and we would just get labelled as troublemakers.

The participants working in the segregated classroom reported that the relationships with the EAs that worked in the inclusive classrooms were not of equal status. They suggested that the unequal status affected the relationship between the EAs, giving some EAs power over others. Brenda suggested that the tasks performed in the segregated setting i.e., changing diapers and feeding, were looked down upon by the EAs in the inclusive classrooms. 
Well, this particular EA is very versed in technology, so anytime there is anything to do with the technology that is going on in the school she heads that, or if there is a grade eight trip, or if there is something going on in the school like the graduation or plays or meetings with principals she seems to head all of that stuff and therefore all of her EA responsibilities fall down to 'oh well they can do that because I need to do this' and I think in a sense it is a fault also of the administration in the school because they take advantage of her abilities and she is very versed in her abilities because guess what she doesn't have to stand around and change diapers.

The participants talked a lot about principals and teachers and how they acted as leaders in the schools and classrooms. At the school level all participants were required to report to the principal. The teacher was seen, by the EAs, as the leader in the classroom and the principal would have the final word on the assignment of EAs in the school. The participants describe the relationships with some of the principals and teachers.

Relationship with Principal. One participant reported an incident at her school between another EA and herself. According to the participant the principal suggested that the two EAs simply avoid each other. The problem remained unresolved.

One time we had a principal and we were in a meeting. It was about an EA at the time and she said I don't want to hear you talk about this anywhere to anybody. I know I have felt that I have not been able to say what I wanted to say... it was just don't talk to that EA anymore [because there was conflict] ...it is a long story, but the principal brought me into a classroom with another EA and said to me 'what's the matter don't you like this lady?' and she was sitting right there I said 'I have no problem' and she said whatever we 
talk about in here you are not allowed to talk about in the school and do not talk to the other two EAs about anything. This was not a healthy work environment. It doesn't interfere with my job. I just do what the teacher wants. I have never felt as though I have wanted to do something and been stonewalled, I just believe in just doing what the teacher wants.

Brenda and Carol reported that their principal separated and assigned them to different classrooms one year. The principal made it clear that they were not to communicate if they saw each other while they were working. They felt that this was one of their worst years on the job. Brenda recalled an interaction during that time.

Then it just becomes a job and every year you think if I have to do this and this and this well I will see how long I last and you get through it - cause we wave at each other- one time we hid in a classroom we weren't supposed to talk to each other, but I saw her in the hall way and I pulled her into a classroom and we started talking and all of a sudden the light went on and it was the principal, we were caught - she just walked away and I felt just like I was in grade eight. It is better now, we went through a rough time, but it was kind of like a concentration camp for a while. I wasn't going to let that principal scare me away and now she is gone.

Relationship with Teacher. On a day-to-day basis it is the teacher who supervises and leads the EAs. Alice described her outlook on how a classroom runs smoothly. She told of an environment where there was communication and respect.

I am there ultimately if the teacher makes a decision say about, like discipline - I don't like to use that word but-ok if something happens and the teacher ultimately has the last 
say and I am ultimately there to support the teacher. I am there in the classroom to facilitate the student's learning to the best of their ability. I will best help the students that need help. I'll best help the teacher in managing the classroom in the way that if there are labs, supervising what is going on and if they need any help, do they understand what they are doing, trying to keep them on task, that kind of thing.

Eve also experienced working in a classroom where the teacher was interested in the information and insight an EA could provide.

Well sometimes we are, like we meet with the teacher or the SERT [special education resource teacher] and they want our opinion, I am finding SERTs want EA's knowledge. They want to get they will say to you, you work with that student directly, hands on. You are right there you see them all of the time. You are the one that has the information, and the parents want the EAs in meetings; that is a big change that happens more and more.

Brenda and Carol's experience in the segregated classroom was somewhat different. That teacher ran the class with little input from the EAs.

It is pretty routine and also because of the children, you know they like routine and also it depends on the teacher we have, you know he is very, he is right on schedule and uh, for the most part of the day he runs a program and you run along with it with the children, support the children. He basically runs the program, he basically teaches and says what is going on and you basically make sure the children are following along and getting their work done. You are an overseer, and also if there is any needs, you know with these children if there are any physical needs, like if there is toileting, or feeding or 
if they need medical - if their nose is running or if they are sneezing or coughing. Basic care for these - these are always severely physically or mentally handicapped children. So they are in a classroom and they just need a little support, the teacher can't be running around looking after them. He runs a teaching program, but they need that support.

He is a good guy. He really is, he runs a really tight ship, and he has a really good program...doesn't waste any time, very little free time.

For those kids I think it is good, to a point, because they need to know what to expect and you've got to keep them busy, because within seconds those kids can you know...they can be going in 50 directions. Yeah we sometimes would like him to lighten up a little bit, give them a little more free time, but you know what, that's his preference. Any modification we basically do.

Brenda described a conflict that was going on between a parent and the school. She was told to be at the parent meeting, but the teacher did not attend. Brenda was told that the teacher took the day off. The principal was unsupportive to Brenda during the meeting. "The parent attacked me verbally and no one responded... the teacher wasn't even there; she took the day off because she was so stressed."

Donna felt that some teachers felt unprepared to direct the EA in the classroom. "How they deal with EAs is not taught and some people don't know how to use an EA, and some EAs don't know how to help the teacher without direction."

You get three days if she dies. The participants reported that at times their requests were not approved and that this showed a certain lack of compassion. Carol had to take time off when 
her husband was injured and then she became very ill. There were no inquiries as to her whereabouts or her well being. Carol felt that as part of the school staff the principal should show some level of concern.

I would also like the personal touch, like when I was away when my husband was injured, I told them what was going on and that I may be absent for a few days in case they wondered. The response was no, they wouldn't wonder...we are about people right? When I had HIN1 in the fall the office didn't inquire about how I was. They didn't always get a supply for me either.

Brenda commented on the time Carol was away and there were no supply EAs to replace her. "They would pop their heads in and say to the two of us in there...you guys are ok right? And that was it."

Brenda also recalled a time when she had taken a three day a leave for her daughter's wedding. The principal at the time responded in a way that Brenda had not expected.

And if you take time off, ok I took three days off for my daughter's wedding, oh my God they crucified me. I went back to work on the Tuesday and the principal came in and said 'I want to see you in my office, on your break' so I go in there and she said 'sit down' and I looked at the paper and it said bereavement, and she said 'you get three days off when she dies not gets married.' I could hardly breathe.

Donna noticed with the new department head that there was a more rigid concept of time. The lunch breaks, lieu time, overtime, it all had to be accounted for. There was no flexibility or give and take. 
Well, the attitude now is that because the person in charge is the clock watcher and is constantly watching all the little things, the management things, and not seeing that we are valued. I work during my lunch because we are flip week. So there might be a math test and I have supported my autistic student and ten other kids in the class, so for me to be away [from the math class] on my lunch, especially at the beginning when I was away until half of the class was over I wasn't getting there for the first 45 minutes on a test day. I would just eat my lunch quick and I would just not take my lunch, that was my decision but there was no, the teacher noticed, but there was no recognition [from department head]. So when you would say, 'I have a doctor's appointment, could I leave early' the response would be 'you can work your lunch today' where in the past it was a give and take and often we needed to stay until 3:00 (when our day officially ended at 2:45) because the buses were late or broke down we didn't think about it. It was a give and take and so therefore you gave more because you felt valued.

Donna clarified her position by reporting that she would never compromise the success of one of her students because of her relationship with the head of the special education department.

I always give when it is to the benefit of the student. I do not give when it is to the benefit of the department. If she needs something photocopied and its going to take 10 minutes and I am leaving in 5 minutes I'll say 'I'll do that tomorrow morning, I don't have time now.' Whereas other times I would have done it without a thought and other times I wouldn't have been asked because that person would have gone and done it herself. Usually by the time you write out what has to be done and how to do it, you could have done it yourself. 
Go with the flow. Eve felt that as an EA it was impossible to know everything. Her advice was to try to go with the flow and try to understand where the principal and the department head were coming from.

I don't understand the rhyme or reason for why things happen. And if you spend all of your time trying to figure it out you will be a miserable person and if you ...it's just not worth it. So it is probably best to go with the flow as best you can. Ask when you can ask questions and investigate when you are able to and if it is important to you will sit down with your director and you say "this bothers me how come this is happening can you find information.' Because they are probably just as upset as you are, they're losing a staff, now they have to redo the schedules. I wouldn't want to have to keep planning schedules. I was a supervisor in a daycare. I know what it is like, and you are always the bad guy.

Alice pointed out that the EAs sometimes should give the special education teacher and the principal the benefit of the doubt. They have difficult jobs and sometimes are under a great deal of pressure, or sometimes there is a personality conflict.

...sometimes I don't know if they realize how they are actually saying it. You know sometimes they [department head/principal] could just have so much on their minds that, you know, sometime they don't realize how they are coming across. And then the other factor too is that I know there are some things that affect me at home that I try not to bring it to work. But there's times when it does, so I don't know if there is something else that is playing on their minds; that they aren't totally aware of how things are being expressed either. So I try to give somebody the benefit of the doubt because there times 
when it is appreciated and then there are times you have to chalk it up to it's just someone's personality and do I need to own that? If I don't need to own that then I am not going to. The older I get the more I realize that.

\section{Similarly Eve explained,}

You have to give everyone a fair shake; it's like kids playing in the school yard if one friend tells another you are not to like that person it is prejudgement, on some, it goes for everyone, staff and students. Personalities are always going to collide; you are never going to get along with every single person that you meet. Yes and I find that it brings less stress if you don't take that stuff personally.

Eve also believed that nothing was gained by a negative attitude.

I enjoy my work I never get up in the morning and say 'Oh I have to go to work this morning' I only do that when I want a weekend [laughs] but I don't go to work thinking this is awful. I have a different attitude. I try not to bring negative into it. These students need our help, you don't, and we're just there with them for so many hours a day and if you are professional and you don't take everything personally, you can't take everything they say and do personal [other staff] it doesn't bother you as much.

Communication. Within the education system in Ontario there are several levels of bureaucracy from which information must flow. The Ministry of Education informs the school boards, the school boards inform the schools (principals) and the principals inform the teachers. Accurate communication between levels is of the utmost importance and the successful relay of information is at the mercy of the messenger. The participants all, not only reported on the importance of open communication in their job, but also the lack of communication. 
Broken telephone. Brenda discussed her views on her school's understanding and interpretation of the school board policies regarding students with special needs. "I think it gets lost somewhere. What does anybody know? It gets lost between the principal and the teacher never mind the school board and the ministry. That's my opinion on that." She felt that the people working at the school board level should have a clear vision of what it was like to work on the front lines.

If somebody would get involved along the way other than just the EA, then maybe you would get an individual who would have the knowledge from the bottom up. You know like the guy who started out sweeping the floor and worked his way to be the president and he was the best because he knew everything.

Eve reported that she didn't always feel that she had enough information.

Not knowing as much as we should before a student starts. I think EAs should be told more. Especially if you are working with a student and if there have ever been safety issues in the past. We should be informed. Sometimes it almost seems as though we are not being told, and the school you are working at isn't being told either. You don't know where the information has stopped. So it's kind of...that to me is the most frustrating part. You want to help the student, or work with the student as best you can, but sometimes you are not sure. Like if a student has certain things that are triggers, behaviours and rage, we need to know this stuff sometimes we are not told we learn the hard way.

Eve reflected that perhaps it was a communication gap, "I don't think it is bad admin. I just think that somewhere down the line the kids change from school to school. Something gets 
lost" or she thought that it could be the school board's way of protecting the student. She continued,

Yeah, I don't know... or it is just not told. I don't know where the problem is. That's why it's frustrating. If I knew where it[student information] was I would go there directly and I am sure other people would too, but that is a hard thing, and you don't want to take, if a student has had a negative experience at one school, I really don't want to take that pre-judgement already before the student gets to you. You may work with that student and have a totally different relationship and sometimes it's best not to know so much.

Is the school board aware of who really gets the support? Brenda expressed her frustration with the way the school board allocates the number of EAs.

We have all these children coming into the schools and the administration says yes we have all of these programs and administration sits back and what are our needs - they say we have this many kids, we need this many EAs and that doesn't mean they allocate the support to the children who are supposed to get it - the parents are not a part of these decisions. So we get little Johnny and he has all of these needs - oh good now we get two more EAs, because we need them in primary because those teachers are going crazy, but what about little Johnny? Oh he will be ok with this amount of support and the two new EA allocations will be dispersed all over the classrooms. You know there are EAs in there and he will surely get support.

Donna was also frustrated because she saw so much need for support and not enough EAs. She felt that there are many students who have fallen through the cracks because of low support. 
One behaviour, one girl who was a behaviour ... so again I saw that I wasn't needed in that class. So I am not going to go to a class where I am not needed. My student was so frustrated he had chosen not to go. I knew from just passing by the room that the teacher had a class of really low kids and he had no EA, because you will only get EAs for autistics. You don't get EAs in this board for low and slow. You do not get an EA. Extreme behaviour and autistic, that's who we support.

Time. Eve knew the policy information was available, but didn't feel as though she had time at work to look up items on the school board website which pertained to the EAs. She did not think there was an appropriate time to do it.

I don't know the allotment [for our school]. We have on our website. We do have it. Our union has a lot of information, but it is time too, we don't have a lot of time to sit at the computer. Is it the appropriate time to do it when there is a student sitting beside you? So then it becomes... and that home thing once I get at home my mindset is not at work, but if it were an emergency thing and it were so important, then I would have to find the time.

Eve indicated that she was interested in knowing more about how the school board works and how decisions are made. She agreed that a professional development day would be well spent learning about the relationship between the Ministry of Education, the school board and the individual schools.

It would give us an insight as to how the board works so that we are not always going "why are they doing that?" It would be good for us to have insight into how they think and work so that we understand it. There are so many people working at so many 
different levels how does everybody know what everybody is doing and what for? I just find it really, really hard when they cut EAs and I could understand if the EA really wasn't needed, anywhere I have worked and they have cut them, we have been shocked.

Where is the 'EA' in teamwork? Donna expressed her frustration at the way EAs are left out of the teaching team.

EAs are in room $\# 112$ from $X$ to $X$ time, if there was something to discuss with them. So a teacher goes to a SERT, and says 'here's what is going on' and goes to the meeting, so the teacher is at the meeting but not the EA. So, the principal is preaching teamwork, and the department head is preaching we have to work as a team, and you have to support your team, but it's like wait a second you know what? We are being bench warmers.

Donna went on to explain her feelings about the term staff meeting.

How did you know that that is my pet peeve? I don't think they should be called staff meetings because the staff members in the school include secretaries, custodians, and EAs as well as faculty. So if you want to have a staff meeting and only invite the teachers call it a faculty meeting, would we benefit from going to the meetings? Probably not, because most of it is teacher directed, but do I think there is a place if you expanded it to include all staff, rather than just on days when there are announcements like when they announced that the principal was leaving? And when we get the email we all go 'are we supposed to be there?' we are never there otherwise. 
EAs' communication with teachers, principals and parents. Alice felt that many

teachers sent their students to the resource classroom without sending clear instructions about the assignments.

If there are any questions you have to call the teacher for clarification. Cause for instance there was one male student who came in and he was supposed to have handed in the assignment a month ago and he hadn't handed it in and I had to go through it and see what needed to be finished... it was labour intensive in that he had to wait so that I understood what that paper was asking for him.

Brenda and Carol worked with a teacher that did not plan specific meeting times with them to discuss the students or the programming. He did communicate when there were pressing questions or concerns about a student.

Maybe in the moming before the buses arrive, the teacher may bring up a subject of a concern: 'what do you think with a certain child?' 'Maybe we should be doing such and such with him' you know. But there is no set, 'oh we need a meeting' or set, "we need to talk', 'we need to plan.'

The timing of critical conversations about student progress seemed to happen in a rushed fashion before or after the class. For Donna this was not the optimal situation. She would like to have had special time just to meet and talk with the teachers about the students that they support.

Those conversations, because there is no time in the day to information share, so you try to do it in the classroom which is not the ideal situation. The ideal situation would be to have ten or fifteen minutes a day to say EAs are available here, come and talk to us. 
Communicating with the families is typically a function of the teacher. Brenda and Carol discussed an interaction with one of the families at their school.

The other day I picked up the phone and one of the mothers was on there and I think she just needed to talk because he had fallen. He had fallen at school and he got banged up pretty bad. She just wanted to ask somebody what happened... dad came to pick him up, and guess mom was a little shaken because it is very hard to communicate with this child and she just wanted someone to talk to. I mean she talked very little about the accident, more about him and the program. She said that she felt so good just talking to someone... he [the teacher] didn't mind that day, but as a rule we don't do that. We write very little in the communication book, because you think no I better not write that. We are not allowed to write anything negative it has to be all positive.

Donna has experienced a change recently. Some of the parents have come directly to speak to her and not always the teacher. "...the parents when they come to the school will come and find us rather than speaking with the SERT (special education resource teacher) or with the department head or with the teachers, because we are the ones who are with their child" Eve also discussed the change she experienced this year.

This year any student I have had, I have been at the meetings. So I see a change happening, for the better. Because the parents also need to see the face of the person who is working with their child, I would want to know, and they want to know what things in class the student is bothered by, what makes him happy. Parents want to hear the good stuff too. And when you go in and say that you have seen an improvement in 
the last few weeks, their faces light up, because a lot of times these meetings are negative.

EAs communicating with EAs. Some of the participants reported positive communication between themselves and other EAs. There were examples of information sharing and close supportive teamwork. The participants reported that in some cases the communication between EAs depended on what position they held in the EA hierarchy.

Eve reported on her experience,

It depends if you know the student from the past, if you have worked with them before they will ask you questions on how it worked. I find that is really good about the team I work with. If you have worked with a student, you will share your past experiences of what has worked and what hasn't.

She continued to recall a difficult time working with another team of EAs that she did not see eye to eye with. Eve felt that if their disagreements affected their jobs she would have to talk to them about it.

You have to, if you are going to be a team player, if you are going to work as a group you have to talk about it, you have to tell the other EAs if you are upset about something or ...

Yes, on a professional level or say 'I don't understand why that happened' because they may know that student in a different way and sometimes you'll go 'oh I've never thought of it that way' and then 'ok I get it now.' You have to respect them professionally you are not going to agree with every single person that you work with 
but give them a chance because they may know something that you don't know and I am learning that...

It all comes down to communication, you have to ...it is the team communication that I find so important.

Brenda and Carol, who work together in the same classroom, reported on the importance of their team:

Generally good, but I think it is only because we have such a good EA team. Because you are working with your friends and you have got good support. If you have a bad day, you go for coffee.

But they also found that outside of their team, communication with other EAs was difficult. Brenda and Carol work as a team in a segregated classroom and the other EAs involved in the difficult interaction worked in a general education classroom.

Yes, when a peer of yours is telling you and wasn't on our team or in our classroom, and she is quick to tell you what to do and it just sort of grates sometimes we have all been doing the job the same length of time, but somehow she seems to have gotten more power. She doesn't care about anyone's feelings she just jumps in to tell you what to do.

Sometimes she does it like she is talking to the child 'you are going to do this now' and you know she is telling the EA.

Union communication. The participants did not discuss the role of the union in detail. There were few comments with regard to communicating with the union representative or what 
the union really does for the EAs. Donna was the only participant to share her views on the union.

The union notifies us...it is hard to know what policy affects us because unless you are watching all the time...I was politically active in the board at one time and I know about the PPMs (policy/program memorandums) that come along and ... do you think that I would do this job without a union? No. Do I think that our union reps are doing the best they can? Yes. Do I think we are in the wrong union? Yes.

Donna felt that the present union was fulfilling their obligation, but that they may be better served by the same unions that the teachers belonged to. She reported that it was her understanding that the teachers did not want the EAs to be members of their union.

Change. According to the participants, change was not always welcome but it was often necessary. In the education system the EAs saw change at all levels, from the school board, to the school and in the classroom.

Changing from the segregated to the general education classroom. The schools in Simcoe County are working toward eliminating many of the segregated classrooms. The participants were asked to share their understanding of inclusion during their interview. Alice believed,

So my take on inclusive education is that a child with special needs is included in the classroom and is able to work in that classroom to their fullest potential and the needs that or the accommodations that need to be made for them should be made. Sometimes I find that for some of the students the time frame of the class they are in is too long for them. So it is very hard sometimes to deal with behaviours because of that and 
sometimes the longer periods are good if you are trying to work at something that gets finished. But if a student comes in from home or has had an outburst or whatever sometimes they are so tired that they need that calming time and that period of time is too long.

Brenda felt that,

I think they need to be integrated more. I think they need that special place, they need that but I think they also need exposure to anything that they would fit into, you know? There are classrooms and subjects and ... I think like any of them they would be great. Put them in a regular class I think they would learn more being social with the other kids in the classroom, and that past has proven it. The other children accept them better, they get to know them, and they develop a relationship with them.

Carol felt that inclusion should be looked at in terms of the children and the staff.

I thought it was our kids going out into the school...: I don't think it is totally inclusive you know, I think there are a lot of little pockets of people. That goes for the staff as well as the students.

Donna was concerned about the students with special needs disturbing the typical students. She felt that the children with special needs should be included as long as it was appropriate.

Inclusive means to me that as long as it is possible and not to the detriment of the other students, that every child should be involved and should be integrated into appropriate classes. i.e., you don't put a student who is a screamer, runner, who needs to be physically active into a history class for sitting. You integrate that child into a phys.ed 
class where spontaneous running around would not be viewed upon as disruptive behaviour.

Eve paused as she thought about what inclusive education meant to her and to her school. She indicated that the definition was not clear to her.

Inclusive education, wow I haven't even thought of that [long pause] I am stumped.... is it including students into the education field [system]? Yeah, all children of all physical and mental disorders are included in school. They are entitled. I do believe they are entitled. I fully... you know you are not asked to be born a certain way; you can't be punished for it. Now we have to analyse whether we are doing them any good, what is best for them? But I don't believe that anybody should be excluded. More and more they are getting... I can see how sections of the school are segregated. You have your different shops, you have your different programs and they can be completely separate and it can be... it is public awareness. You have to teach students who are neurologically ok who we consider 'normal' to work with students with special needs. You are not going to go through life never meeting someone in a wheel chair or never meeting someone who uses a cane or never meeting someone who is autistic. You have to learn to have tolerance.

She felt that the importance of inclusion was the social learning by all students.

I think it is a social learning as well. We are teaching tolerance we are teaching compassion and empathy because it is a learned behaviour. If you have never met anyone in your life who is in a wheel chair and you are older, you will stare at them like there is no tomorrow because you...it's an ignorance you have no idea. Or 'how did 
they get that way?' Or 'oh my goodness' that poor person. Most people who are handicapped don't want you to say 'oh poor thing.' They want to be treated just like we want to be treated.

Scheduling changes. The participants described other changes which they faced on a daily basis and how they managed. Donna was taken out of a classroom without notice.

Yes, unexpected changes. Yeah, I was taken out of English, I guess in April, I was justno notice, just today you are no longer supporting an autistic student that you have been supporting all year. As well as there were several other IEP students, like you are assigned one student but this English class which had 30 students had 18 IEP kids. So obviously I didn't spend my time sitting with my autistic student that I was "there to support." Obviously I worked the room and worked with whoever else was struggling and needed assistance.

She commented that the teacher had not been notified of the change either and she did not feel it was her responsibility to relay that kind of information.

No, no, no this was a scheduling change. This was 'I need you somewhere else I am taking you from there, I don't know if you are still needed' and that was my first question, when I went to talk to the teacher was 'were you consulted and do you know that I am no longer with you.' And the answer was no. I don't feel that it is an EA's place to say, 'by the way you don't have an EA anymore.'

Brenda and Carol remembered a change that broke up their team. They described the change as removing one and leaving the other behind in the classroom. 
...different years they have separated us. We trade off if I am in life skills in the morning she will come in the afternoon. And there will be a grade three class that needs support so she'll go in the morning and I will go in the afternoon. Or sometimes they completely removed one of us for the year and put us in a classroom for a change and left one of us behind.

Carol reflected on some of the changes that have been made in their classroom. She felt that often support was taken away and not always replaced which left them shorthanded. "Yeah but then it [the change] leaves our team short."

Flexibility. Alice was usually willing to volunteer for different assignments. She felt there was a need for flexibility in her job.

Ok so there are times when I volunteer, and other times when I am told. Because I can be flexible, only because I have learned to be flexible through having my own children that also too by working as a nurse you know that there are things that are just unexpected. So if I am told that this needs to be done then it doesn't really bother me.

She continued to discuss some of the changes that she had experienced over the past year. Her feelings were,

For me it was going out into the school [away from the segregated class] that was different, but really you never know where you are going to be. Even in your life, there are twists and turns so either you are going with it and do the best you can or you can fight it. 
Brenda related the idea of flexibility to willingness and ability to switch duties within the same classroom.

You just slide into it, you know? I may look over and she [Carol] will be doing something with the student that I was working with, so I will say ok [student that Carol was previously working with] and will do something with them.

Change is difficult. Eve looked at change as a reality of the job. She acknowledged that it was difficult for new EAs,

It is a big transition for EAs to have to move from one school to another school. You've got to get to know all new admin, get to know all new teachers, their teaching strategies, even working with three or four different teachers every day. Each has a different teaching strategy that you have to get to know. And they have to get to know you whether you two are going to connect and get along.

Eve reported, that staffing changes were also difficult for the staff staying on a the school, I find them [the changes] disruptive when we are told Friday in the middle of the day that an EA is leaving, like we have lost that position and all of a sudden we are leaving the school on a Friday. You have an EA who is crying. They have lost their job because the board has analysed how many we need. I don't know what transpires. They have just settled into their schedule, we have just settled into ours and now we have to cover all of those students too... I find that the hardest.

Coping strategies were useful to Eve and she shared some of the ways she managed the stresses associated with change at work. 
I have learned that over the years, I know that there are others who don't have that theory, but 1 think daycare taught me, daycare really taught me that you have to...there are things that stress you, oh yeah. You have to be able to de-stress and you have to stop and look before you react, stop and look at the situation before you react give yourself that few minutes of breathing time and you will be better. Yeah sometimes if you react too quickly you are not being fair to yourself or the student.

Education and job status. Some of the participants expressed their lack of employment alternatives in terms of their age and education. They felt that they wouldn't be able to get a better job anywhere else.

Brenda remarked that her background, education and age have limited her options for employment. She pointed out that she was hired to this job with a high school diploma and commented that if she didn't have this job where would she work? "Well look if I left that job where would I go: IGA? Tim Horton's? Seriously, at my age and my qualifications. Or I could go to an office, but even then I am not up to date with those skills."

Carol, who works with Brenda, was also hired as a high school graduate. She was later mandated by the school board to upgrade and get her educational support worker certificate (ESW). "...but that is what they said 'this is what you have to have' and I went back and spent, what, three years at night school. It was a long three years with little kids, but I got my ESW."

Each of the participants interviewed were women. They all commented on why they became educational assistants. Alice stated that her children's learning disabilities and the irregular hours of her job at the hospital prompted her to consider leaving nursing. 
I worked in the hospital but then when I moved up north there was no resource up there and I have three children with learning disabilities. One with dyslexia and reading comprehension problems, the second one was $\mathrm{ADD}$ and the third one was a gamut of different problems and so I stayed home for about 10 years. And I figured I may as well do something that was conducive to my children's hours than working shift work and holidays. So I went back to school and got my DSW developmental service worker from the college and because where I was living it didn't allow you to go in with your nursing, you needed either your ECE or DSW.

Brenda recalled that the job came along and she thought she would take it while her child was young.

I applied to the school board actually as an administration assistant and they needed [EA] supplies so I just did some supply work as an EA. And I did it for about a year and then there were openings for full time and so I thought I would give it a try... My little guy was full time [school]. I was only going to do it just for a short while, but, um anyway I am still there.

Carol stated similar reasons, but that she wasn't even sure that she wanted to go back to work.

Twenty years ago I was a stay at home mom, and volunteered at the school and the principal called and offered me a job. I remember when he called me I told him I would have to let him know, I didn't want to go back to work (laughs).

Donna explained that her involvement with her son's school council drew her closer to the principal and eventually he offered her a job. 
...they were desperate, oh so before that from 1985 I was chair of parent councils. In fact I was still sitting on the parent council and chairing them when I got the request when my son was in grade nine to, if I could come in and work for six weeks because they were desperate. They had just got funding for an EA. I was the only out [in the classrooms] EA. There were three EAs in life skills, but I was the only out in the school EA and it was supposed to be from the beginning of school until thanksgiving and thanksgiving turned into Christmas, Christmas turned into $2010 \ldots$.. got grandfathered in. I was lucky that they changed the rules as to what they would accept as qualifications were and the principal that I was under, because he was brand new, he fought.

Eve's reasons for becoming an EA were related to her career plans and found the hours fit nicely with her own children's schedule as well.

Ok, I have early childhood education. I started off in daycare and then I started to work with children with special needs, children with speech problems and several other disorders and then I decided that I would work for the school board. Or try to work for the school board because it was an area that I liked to work with children with special needs and I get to have the hours that my children have... yeah it's kind of like it works with young families, I like to be home as much as I can.

EA training. The school board offers the EAs special training courses throughout the school year as well as on professional development days. The participants were mixed about the appropriateness of the content of many of the courses.

Donna felt that the focus had shifted in the content of the courses offered, 
Previously, for the first five or six years the board was really good at offering stuff after work. But obviously the stuff we did at the board from 4:30 to 6:30 was on our own time, but we didn't have to pay for it and they offered phenomenal courses. They offered one course that I took, about six or seven years ago on chair transfer, on how to move-how to transfer to a chair, how to transfer to a toilet, how to use your lifts all of those little things. Obviously each disabled child has a different set of requirements, but these were general how to protect your health. So you do not get hurt while lifting, while shifting, how to protect their privacy, so that was one course. We had a really gọod PD last year it was on behaviour is not intentional, on foetal alcohol syndrome kids. Most of the courses offered now because of PPM 140 are autism based; everything in education now revolves around PPM140 because the Autism Society of Canada is encouraging parents to sue. So that's some of the things...five years ago our PD was a bit more diversified, but now I find that the PD is very autistic based and I think it is a direct consequence of PPM 140 that they must...

Eve commented on how much she valued the training that the school board offered her,

If you go on the website, there are many that are offered now. Sometimes you get extra PD training because you are working specifically with certain students and they want you to have special training, which to me I am grateful for, because if you didn't thave the course] it would take you twice as long to learn. You have to learn the hard way. I like thinking 'gee I never thought of it that way', or 'I am going to try that next time'

She also points out that there are many EAs who do not take advantage, 
There are some who don't do extra after school hours. Especially the older they get and the closer they get to retirement, I don't think we are ever at a point where we can't learn we have to constantly be training for these students because diagnoses change all of the time you can't go with an old system.

\section{Interrelationships between the Categories}

Table 3 indicates the initial placement of subcategories within the corresponding main category. It is evident however, that the subcategories could be used to define more than one main category. 
Table 3

Main Categories and the supporting Subcategories

\begin{tabular}{|c|c|c|c|c|}
\hline $\begin{array}{l}\text { Roles and } \\
\text { responsibilities }\end{array}$ & Relationships & Communication & $\begin{array}{l}\text { Managing } \\
\text { change }\end{array}$ & Training \\
\hline $\begin{array}{l}\text { Supporting } \\
\text { students }\end{array}$ & $\begin{array}{l}\text { Do not } \\
\text { question or } \\
\text { speak your } \\
\text { mind }\end{array}$ & $\begin{array}{l}\text { Broken } \\
\text { telephone }\end{array}$ & $\begin{array}{l}\text { Moving from } \\
\text { segregation } \\
\text { to inclusion }\end{array}$ & $\begin{array}{l}\text { Lack of } \\
\text { training }\end{array}$ \\
\hline $\begin{array}{l}\text { Teaching social } \\
\text { skills }\end{array}$ & $\begin{array}{l}\text { Equal/unequal } \\
\text { status among } \\
\text { EAs }\end{array}$ & $\begin{array}{l}\text { Not enough } \\
\text { support to go } \\
\text { around }\end{array}$ & Changes & $\begin{array}{l}\text { Shift in focus } \\
\text { of training } \\
\text { courses }\end{array}$ \\
\hline $\begin{array}{l}\text { Tending to the } \\
\text { physical needs } \\
\text { of the student }\end{array}$ & $\begin{array}{l}\text { Relationship } \\
\text { with the } \\
\text { principal }\end{array}$ & Lack of time & Flexibility & $\begin{array}{l}\text { School board } \\
\text { offerings }\end{array}$ \\
\hline $\begin{array}{l}\text { "other" duties } \\
\text { as assigned }\end{array}$ & $\begin{array}{l}\text { Relationship } \\
\text { with the } \\
\text { teachers }\end{array}$ & Part of the team? & $\begin{array}{l}\text { Change is } \\
\text { difficult }\end{array}$ & $\begin{array}{l}\text { Same job } \\
\text { different } \\
\text { training or } \\
\text { different job } \\
\text { same } \\
\text { training? } \\
\end{array}$ \\
\hline $\begin{array}{l}\text { Managing } \\
\text { student } \\
\text { behaviour }\end{array}$ & Compassion & $\begin{array}{l}\text { EA } \\
\text { communication } \\
\text { with principal, } \\
\text { teacher and } \\
\text { parent }\end{array}$ & & \\
\hline & $\begin{array}{l}\text { Going with } \\
\text { the flow }\end{array}$ & $\begin{array}{l}\text { Union } \\
\text { communication }\end{array}$ & & \\
\hline
\end{tabular}

Table 4 illustrates how the categories were refined to two main categories.

For example, lack of training was added to the category of relationships. One participant lacked formal education (training) which made her feel as though she had no choices and that she would not get another job anywhere else, so she would just do as she was told. Another example was seen in the issue of schedule changes. Often the EAs would not have any warning about these changes, and what was discussed was the manner in which the change was communicated to the 
EA. The EAs felt that the students that they supported needed to understand that change was a possibility and should be told before it occurred. The issue of schedule changes was added to the category of communication.

Table 4

Refining the Categories

\begin{tabular}{|c|c|}
\hline Relationships & Communication \\
\hline $\begin{array}{l}\text { Do not question or speak your } \\
\text { mind }\end{array}$ & Broken telephone \\
\hline $\begin{array}{l}\text { Equal/unequal status among } \\
\text { EAs }\end{array}$ & $\begin{array}{l}\text { Not enough support to go } \\
\text { around }\end{array}$ \\
\hline Having no alternatives & Lack of time \\
\hline Supporting students & Part of the team? \\
\hline Teaching social skills & $\begin{array}{l}\text { EA communication with } \\
\text { principal, teacher and parent }\end{array}$ \\
\hline $\begin{array}{l}\text { Tending to the physical needs } \\
\text { of the student }\end{array}$ & Union communication \\
\hline "other" duties as assigned & $\begin{array}{l}\text { Shift in focus of training } \\
\text { courses }\end{array}$ \\
\hline Managing student behaviour & School board offerings \\
\hline Principal as a leader & $\begin{array}{l}\text { Moving from segregation to } \\
\text { inclusion }\end{array}$ \\
\hline Teacher as a leader & Scheduling changes \\
\hline Compassionate leader & Flexibility \\
\hline $\begin{array}{l}\text { Going with the flow-do not } \\
\text { fight it }\end{array}$ & Change is difficult \\
\hline Lack of training & $\begin{array}{l}\text { More communication with } \\
\text { teacher about role in the } \\
\text { classroom }\end{array}$ \\
\hline
\end{tabular}




\section{CHAPTER IV}

\section{Discussion}

This study explored the perspectives of educational assistants in Ontario classrooms. I examined the structure of the EA's working environment by questioning their relationships with teachers, principals, and other EAs and by discussing the level of communication found in those relationships. The findings indicate that the EAs feel powerless. Based on Friere's theory, the EA's feelings of powerlessness to change or clearly understand their role in the classroom is an issue which is often overlooked by the school boards and principals. The principals' and teachers' task of managing the students with special needs in the general education classrooms is simplified if the EAs follow directions without questioning the decision makers. According to Friere (1970), "the interests of the oppressors lie in "changing the consciousness of the oppressed, not the situation which oppresses them, for the more the oppressed can be led to adapt to that situation, the more easily they can be dominated." (p. 74)

Lack of knowledge and clarity has allowed the education system to marginalize and exploit the EAs. All of the participants reported a lack of clarity in their roles and responsibilities, and if this is true there may be opportunities of exploitation. The findings reveal that most of the participants lack a basic of knowledge of the school board policy and the role of the union. This apparent lack of knowledge and lack of desire to learn evoked certain apathy among the group of participants. The participants did not report actions taken to change their work environment; they felt they should just do their jobs without asking questions. The present education system could be perpetuating societal attitudes held for those involved with special education. If the education system continues to treat the EAs as a marginalized group within the 
school community, they will become marginalized. The principals and teachers take the EAs on as marginalized group to "integrate and incorporate" them into the education system and have them remain marginalized (Friere, 1970 p. 74).

To fully understand the perspectives of the EAs, the major factors which influence their ability to perform their responsibilities were identified. Throughout this study there were five main categories which were found to influence the educational assistant's perspectives: 1) roles and responsibilities, 2) relationships, 3) communication, 4) changes, and 5) training. The interrelationships between these categories and their subcategories exemplify the complex nature of the EA's role in the Ontario classroom. Relationships and communication emerged as the core categories.

\section{Relationships}

The data suggested that the relationships EAs had with the other members of the school community were extremely important. The findings highlighted some of the power relationships present in the schools. The category of relationships included the EA's interactions with principals, teachers, other EAs and parents. More than once the participants reported not feeling appreciated, which resulted in low morale. They felt as though they could not speak up without fear of reprisal and that they had few alternatives in terms of employment. These findings were in agreement with Bourke (2009), Giangreco et al., (1997) and Giangreco et al., (2001), who investigated the role of educational assistants. The research revealed issues of powerlessness, lack of identity, low salaries, and issues of respect and appreciation, all of which had an effect on morale. 
Deep feelings of powerlessness. The participants described the hierarchy of the school, where principals and teachers had authority over the EAs. From the participant's perspective, they were working in an environment where there was little compassion and this made the EAs feel unappreciated and powerless to speak their minds.

The relationships between the EAs and the principals and teachers were found to be important and further examination uncovered evidence of the power relationships which were present in the school system. Each school had a leader which enforced the structure of the school system. Therefore the relationships between the EAs and principals or EAs and teachers were constructed like most other power relationships replicated in society. Each party knew what to expect from the other in terms of the dynamics of their relationships, and the EAs understood that they were assistants in the classrooms. This understanding does not negate the need for respect and appreciation. From the perspectives of most of the participants the lack of respect and appreciation contributed to the feelings of powerlessness present in the principal-EA relationship.

Roles and responsibilities were discussed in terms of the daily tasks assigned. None of the EAs reported being asked to perform tasks that were not listed in their job description. There was, however, the ominous "other tasks as assigned" offering a potential loop hole for those in charge. These other tasks often included major cleanup jobs primarily completed by the students with special needs and their EAs. Carol recalls a job assigned to her group of students with special needs. They were given the task of cleaning up all of the pinecones from the school yard. The findings indicated that the EAs in the segregated class felt that they were assigned tasks that no one else wanted to do. Even their daily tasks were not attractive to many of the EAs in the school. Brenda spoke of an EA who was always volunteering for special activities "....at least she 
doesn't have to stand around changing diapers." The participants described having to take on the workload of that EA when she was on 'special assignment'. The findings also indicated that there were power struggles among the EAs. All EA job postings were equally ranked. General education classroom jobs were not ranked higher than segregated jobs, but it was interesting to note the underlying attitude that this was the case.

EA's lack of training was related to the issues of relationships, through the perceived elimination of choices. One participant felt that, because of her lack of training, she had no alternative but to work as an EA putting her at the mercy of the principal and the school board. It stands to reason if she feared losing her job she would not question those making the decisions, even if it affected her job. The hiring practices of the school board now require all candidates for the position of educational assistant to at least have a college diploma in a related field. These requirements may eliminate the occurrence of this power relationship which currently exists.

In some situations, participants reported that power among the EAs had nothing to do with training. The participants assumed that if an EA could become indispensible to the principal in some way, then the EA was able to have more control over her tasks and assignments. For example, participants took on special jobs that were outside of the job description, but did not consider the tasks as out of the ordinary. One participant was in charge of a lunch program for her students with Autism and she was thrilled to do it. Patterson (2006) found that some of the EAs enjoyed the added responsibility of tasks above and beyond their regular tasks.

In one of the participant's journals she wrote about not knowing what to do when she found herself in a new classroom, she wanted to be effective and efficient, but the teacher kept forgetting that she needed direction. The EA "felt like she was bugging the teacher", but did not 
want to leave the student hanging and was forced to keep asking the teacher for help. This was also found by Giangreco et al. (1997), if the EA was not clear about what the responsibilities of the assignment were, the EA's presence in the classroom would have a negative effect on the student with special needs. According to Takala (2007), if the teacher collaborated with the EA and clearly indicated what they could expect, none of the confusion would happen. Takala's (2007) finding was that teachers did not necessarily assume that this was part of their job. These studies were exploring the relationship between the EA and the teacher. In both studies the lack of EA training would be evident. The EA was dependent on the teacher.

What was deemed most important by the participants was the way in which they were treated while they were doing their job. EAs understood that their status was that of the assistant, but it was still important for them to be treated with respect and appreciation. There were indications in the findings that EAs had a strong desire to be included as one of the members of the educational team. This action of including them would indicate that they were valued by the teacher or the principal. Giangreco, et al. (2001) suggested, that the EAs would have higher job satisfaction and retention if they felt valued.

EA subculture. The EAs form a very distinct group within the school community. They are drawn together by the similarities of their job description, their salary level and their social stature in relation to the other staff. The relationships within this subculture tend to focus on the elements which all members have in common. The camaraderie emerged in a subculture of the education system, where slightly disparaging language was used when referring to the staff and in particular the students with special needs. A few of the participants referred to the EAs in general as 'pond scum' or 'sludge' indicating where they saw themselves situated in the school hierarchy. There was only one group who fell into a lower category than the EAs and that was 
the group of students with special needs. The fact that these students were ranked lower seemed to give the EAs permission to refer to them in slightly derogatory terms. The students with autism were "the autistics", the unidentified students who were not really eligible for official support were the "low and slow", a child who exhibited disruptive behaviour was "a behaviour." This was an interesting finding because it was not clear whether the EAs meant harm by using this language or whether it was almost a code for belonging to this unique subculture of the education system.

Adjusting to change. Change was often received with resistance and anxiety. The changes experienced by the participants were mostly about scheduling and staffing changes. Both could be emotional and frightening. The participants reported unannounced schedule changes that had negative effects on both the EA and the student. In a study conducted by Patterson (2006), EAs reported their frustration at the last minute schedule changes. The EAs suggested that they would be much more effective at their job if they knew of changes in advance, when possible. From the perspective of the EA the last minute change tells them that they are not respected members of the team and do not need to be informed.

When staffing changes were made, the issues became much more serious. Often the staffing cuts were mandated by the school board and the principal was powerless to change the outcome. The skills of a fair and transformative leader should prevail in this situation, allowing the EAs to commiserate and say good bye to the staff member who is leaving. According to Leithwood and Jantzi (1999), a transformational leader is one who has the power to inspire commitment to change from the whole organization. This leader will have the ability to value the well-being of the entire group, will listen to the needs of the organization and will volunteer to be a follower when necessary. However, it was reported that the changes were sometimes 
announced on a Friday afternoon and effective the next Monday, leaving no time for the staff to process the announcement. One participant noted that the rest of the staff also needed time to come to terms with the staff reductions, largely because it meant their jobs would also change.

\section{Communication}

The data suggested that communication was fundamental to the effective operation of a school. Direct communication with the school board and union on matters of policy would enhance the EAs knowledge of their position. As a group they would be more informed and have a greater understanding of the system in general. The data also suggested the level of communication between the EAs and teachers, principals, the school board and the union were not sufficient to empower the EAs. Further, the lack of communication appeared to keep the EAs in a marginalized place within the school system resulting in the emergence of an EA language and subculture.

Action or apathy. The EAs, if given the opportunity, could provide valuable input about the students which they support. Giangreco et al. (2001) and Marks et al. (1999) indicated in their findings that EAs had a desire to be part of the teaching team and that they would be a valuable addition because of their knowledge of the student. All participants reported that they were not invited to meetings, asked for their input, or consulted about the progress of the students. On occasion the teacher asked for specific information about a student, often on the way to a meeting that the EA was not attending. In essence the EAs were not considered part of the teaching team. Some of the participants reported that there was a trend toward EAs attending some meetings, but it was clear they were not invited to all of them. In contrast to the realities of these situations, Carnahan et al. (2009) found that the issues of open communication, shared 
philosophy and respect were high priority items for teachers and EAs. They recommended that the EAs be part of the teaching team.

Within the education system there are several levels of bureaucracy through which information is filtered. Some of the participants reported that the information provided about new students was not always complete and that this posed potential risks to both students and EAs. Most of the participants felt that they did not have a clear understanding of the reasons for lack of support. It did not make sense that there seemed to be increasing numbers of students with special needs at the same time as the school board was reducing the number of EAs. One participant expressed a desire to understand board policy. She felt that it would give some transparency to the staffing decisions in particular and thought the EAs should understand why they were being reduced in number. The findings indicated that the other participants felt that decisions made by the school board were inevitable and unchangeable. The apparent apathy felt by some of the participants could be indicative of a larger problem. The knowledge that the position held little power to effect change removed any desire to try.

It was suggested that the union could be instrumental in providing the EAs with the support and information to bridge the gap. The participants did not demonstrate extensive knowledge about how the union could support them in their jobs. One participant reported that she did not feel there was enough time at school to investigate how to access the support of the union.

Dysfunctional communication. Previously, EAs stated that they would feel valued if they were considered part of the teaching team. Takala (2007) also found that teachers did not necessarily agree, or assume that communicating with the EA was part of their job. All of the 
participants reported that the communication with the teachers was rushed, brief, on a need-toknow basis, or non-existent. In a study conducted by Marks et al. (1999), results outlined reasons for EAs working in isolation. They found that EAs did not want to bother the teachers, were trying to be invisible and hoped that the teacher would be accepting of the student with special needs. Communication and collaboration between the EA and the teacher has been found to improve the learning experience for all of the students (Bourke, 2009; Carnahan et al., 2009; Giangreco et al., 1997; Hughes \& Valle-Riestra, 2008; Takala, 2007).

Communication between the EA and the family has not been encouraged by all schools. Teachers and principals may have felt that the majority of EAs did not possess the required training to discuss the student with the family. It was not listed in the job description as a responsibility of the EA, but ironically the EA was often responsible for the school-to-home journals and was working closely with the student more consistently than the teacher. The majority of the participants reported that parents were approaching the EAs more often than they had in the past few years. They wanted to speak to the EAs about their children. Horne and Timmons (2009) indicated that the knowledge of the student, held by the EA, was a valuable resource for the family and the teacher. They added that the EAs would require extra training to ensure appropriate interactions with the families. The idea of the need for special training is supported by Bourke (2009) who suggested that EAs do not receive enough training, guidance, or background information on the students they are assigned to support. She noted that on-thejob training often consisted of shadowing another EA or waiting for instruction from the teacher.

All of the participants expressed the need for teamwork among the EAs. The participants who worked together were thankful that they had each other, their friendship was characterized as, "among chaos there is stability." They needed that level of cooperation to be successful in 
their classroom. Close supportive teamwork served to share student information, support each other through difficult tasks and to provide camaraderie not found between the teachers and the EAs,

The participants reported that the course offerings from the school board were more comprehensive four years ago. A shift in the focus of the courses was noticed by the participants, moving from the general and practical to the specific. One participant felt that since policy program memorandum no. 140 (PPM 140) which outlined the "direction to the schools to support their use of applied behaviour analysis (ABA)" (Ministry of Education, 2007), more of the workshops and courses offered were related to Autism. The school board did not survey the EAs about what courses they would like offered by the school board.

EAs felt that they should be involved in meetings that concerned the students which they supported. Although the EAs did not possess the formal education that teachers had, the position of an EA held a great amount of responsibility. They supported the physical, social, emotional and academic needs of the most vulnerable students in the school system. Often, their knowledge of the students surpassed that of many of the teachers. All of the participants indicated that their primary reason for remaining in their job was to support the students.

Summary. A reported feeling of powerlessness and a lack of communication in the schools was found to greatly influence the perspectives of the EAs. The structure of the school system and the nature of the relationships between the EAs and the principals appeared to foster the distant and uninformed connection with policy. The desire to be part of the teaching team had consistently been overlooked by both teachers and principals. Excluding the EAs from the regular meetings with parents and school board employees confirmed the EAs as subordinate and 
effectively nullified the value of their opinion. As Donna stated in her interview, "...we are a lot like the kids that we support, we are allowed to sit in but we are never really included in anything." The participants reported that they were never requested to perform duties which fell outside of their job description. The findings, however, indicated that there were times that some of the 'other' tasks were questionable and it was not clear whether the EAs were able to oppose the request.

The issue was not about the EAs wanting to lead in the school community. The EAs wanted to feel that they held a strong and respected position in the school community. They felt that they should be appreciated and trusted to support the students with special needs. If the EAs were included in open and honest communication and were a part of the teaching team, then the students would reap the benefits and be more likely to achieve academic success.

My personal experience with the job of an EA provided me with background knowledge and understanding of the findings. There were however, some findings that were surprising to me. Recalling Ashbaker and Morgan (2001), educational assistants were sometimes parents or grandparents of students within the school and had a great interest in the success of the school and community. The school system offered low wages and frequently only part time positions, but the EA's presence in the school allowed them to be involved in the care and education of their children and the monetary compensation was deemed to be of secondary importance.

I had not expected to find that so little has changed in over 60 years with regard to the participant profiles. All of the participants in this study came to the job for very similar reasons: their own children had special needs, the schedule was conducive to a mother with school age children, it was usually a second income and the monetary compensation was not as critical. I 
had been aware of the feelings of powerlessness when I worked as an EA, but I was not aware of the depth of those feelings and the dysfunction of some of the relationships described by the EAs interviewed. I was shocked at the lack of knowledge the EAs possessed about their rights as employees of the school board and members of the union. I expected the EAs who had been in the job for so many years to have more information and knowledge in this area. The lack of knowledge and the inability or lack of desire to gain more knowledge led me to the finding of general apathy among the EAs as a group; the lack of action to change anything about their jobs. I wondered if I was projecting my own thoughts that if I were to stay in this job, I would want more of an equal footing with the teachers. Perhaps that was not really what the participants wanted, perhaps they just wanted the required tools to perform their jobs effectively; to be informed and respected.

\section{Limitations}

Sample size was a limitation, there were five participants. All of the participants were women and there was low ethnic diversity. Direct observations were not conducted to verify the participant's reports, and were therefore a limitation to this study. The interviewing process did not include the teachers and the principals which would further verify the reports of the participants. The value of the written journals varied from participant to participant. The limitation of the journal was the varying ability of each participant to follow the instructions and to express their thoughts in writing. Given that the journals were the first stage of the data collection, I was able to clarify and follow up with questions at the interview. The interview process had limitations in the ability of the participant to articulate their thoughts. My own personal biases were also a limitation. These biases occasionally presented themselves during the interviews. 


\section{Further Research}

This study adds an Ontario perspective. In this research the perspectives of the EA is examined in the context of the dysfunctional relationships and a lack of communication within the school and how these factors influence their ability to carry out their responsibilities. The current literature generally supports the findings of this study in terms of how EAs perceive their jobs. This research adds to the current literature by providing possible explanations of factors that influence the EAs' feelings about their jobs in the classrooms. The research also reveals what makes them feel powerless and without a forum to express their concerns. A Canadian focus is necessary for new research. Canadian schools and the human relationships within the school structure can be examined further. It would be interesting to widen the scope of this research and conduct a comparative study with other school boards and possibly with the education system in the United States. The results would allow the researchers to gain insight into whether the EAs in other school boards, provinces and countries are facing similar challenges within the hierarchal structure of the schools. It would be beneficial to look into the training process of the EAs. Should the training be more rigorous and comprehensive? Should it be a specialized program, so that all EAs have the same basic education? Would more training address some of the issues pertaining to the marginalized status of EAs in schools?

\section{Recommendations and Conclusion}

There are a number of recommendations which have emerged from this research study. The findings conclude that although none of the participants reported performing tasks which were outside of the job description, it was evident that there were many occasions where the participants were providing instructional support, were alone with the students and spoke to 
parents in a professional capacity. None of these tasks are part of the official job description, but an EA often performs any or all of these tasks regularly. If the findings indicate a trend towards EAs having a greater role in the instruction of certain students, or if the daily operation of a classroom necessitates leaving an EA in charge for a short period of time or if parents want to converse with the adult who is spending the greatest amount of time with their child, then perhaps the job description should be revised. Additional training for all EAs should be a prerequisite to the changes. The school board could offer professional development courses to accommodate those who have fulltime jobs and there could be a specialized program offered as a diploma course at community college.

At the school level some of the participants suggested open forum meetings for teachers and EAs. This would provide a place to speak freely about pressing issues. Another suggestion was to create a year-end self evaluation for the EAs to write and summarize successes and challenges of the past year. This would provide the principals and teachers with valuable feedback and allow the EAs to air any concerns.

The EAs faced challenges in their jobs. Through examining their experiences and feelings, and given the opportunity to ask pressing questions may bring them closer to understanding their role in the classroom. If their experience in the education system has been as Friere describes as authoritarian and questions have been discouraged, then there may be a disincentive for the EAs to question their place in the classroom. It may be in the school's best interest to discourage the EAs of asking questions "...more efficient the less workers ask questions,... and know little beyond the routine task assigned to them..." (Friere, 1989 p. 42). Schools need to have the students with special needs supported by the EAs, but the relationship 
between the EA and the education system is complex and there are pressing issues which must be addressed.

Open and honest communication between the school board and the EAs will be necessary for the EAs to understand school board policy which may affect their jobs, and communication with the union to be aware of the support it has to offer. Open communication with principals and teachers will allow the EAs to become part of the teaching team. They need to be able to share their knowledge to better inform the decisions made about the students. The sharing of knowledge will bring the EAs together as a cohesive and informed group. A group that in partnership with the teachers will ensure the high quality education which all of our students are entitled to.

EAs want the respect and appreciation that they feel they deserve. They need to have a clear understanding of their role in the segregated and the general education setting if they are to fulfill their responsibilities. 


\section{Appendix A}

The Job Fact Sheet

Educational Assistant

Job Description - specific Duties

1. Keep, and maintain record of student(s) activities, behaviour, progress as required by, and under the direction of the teacher,

2. Be aware of any special needs or information pertaining to the assigned student(s)

3. Assist the teacher in the delivery of programs, procedures and activities required to meet the identified needs of individual students or small groups.

4. Assist in the preparation of material when necessary to implement programs for students with special needs

5. Provide reinforcement activities for indentified students as directed by the classroom teacher or resource person.

6. Using the teacher's plan, direct small group or individual while the teacher works with a large group to meet specific objectives, or vice versa.

7. Communicate to the teacher observations of student social, emotional and learning behaviour and discuss any situations or concerns which arise only with the teacher.

8. Maintain confidentiality of information.

9. Communicate to the teacher, observations of student achievement and behaviour directly related to delivery of individual programs.

10. Assist with supervision of student(s) while on field trips, school activities, playground activities, as required

11. Participate as required in staff discussions regarding objectives, progress, materials, program etc.

12. Assist the teacher with the development of special programs and activities as appropriate to the needs of the program and the individual students.

13. Be responsible for toileting/diapering, dressing/undressing, feeding, assist with lifting/transferring/positioning, mobility, as required. 
14. Conduct general maintenance and drill activities as described by the physio/occupational therapist in consultation with the teacher.

15. Assist with the medication to students as required in accordance with administrative procedures.

16. Other duties as assigned by the teacher/principal. 
Appendix B

Ryerson University

Masters of Early Childhood Studies

Research Study

Consent Form

You are being asked to participate in a research project that will explore the educational assistant's perception of their role in the general education classroom. It is important to read the following information before you give consent.

Purpose of the study: This investigation is a part of my Major Research Paper which is a requirement for the completion of the Master of Arts in Early Childhood Studies degree program at Ryerson University. The purpose is to explore the educational assistant's perception of their role in the general education classroom.

Investigator: Marie Hodgson

Under the course supervision of:

Dr. Rachel Langford, Director

School of Early Childhood Education

Ryerson University

rlangfor@ryerson.ca

416-979-5000, 7635

Description of the Study: 
To better understand educational assistant's perspectives of their own role in the classroom you will be interviewed using an in-depth individual interview. The interview will consist of openended questions and will take approximately an hour. All responses will be audio-taped and transcribed. A series of journal entries will be provided to the researcher prior to the interview in order to explore the different perceptions and experiences that occur in the classroom. The interviews will be set up and conducted at your convenience. The interviews will be conducted at a neutral location.

\section{Confidentiality:}

Your responses will be protected throughout the interview process. A fictitious name will be used for you and your organization and any specific identifiable characteristics will be altered. Your perceptions and opinions will be kept strictly confidential by the researcher. Direct quotes from you may be used in the final report but they will not be attributable to you or reveal your identity.

\section{Data Storage:}

The audiotapes, journal entries and transcriptions will be kept in locked files accessible only to the researcher. All consent forms will be stored separately from the data. The data will be stored for 5 years after which it will be destroyed.

\section{Clearance:}

This study has been granted clearance according to the recommended principles of Canadian ethics and Ryerson University's policies.

If you have any questions you may contact:

The Office of the Vice President, Research and Innovation

Ryerson University, 350 Victoria St. Room YDI 1154

Toronto, Ontario, Canada M5B 2K3

(416) $979-5000$ ext.7112

alex.karbanow@ryerson.ca 


\section{Minimizing Risks:}

I do not foresee risks in your participation in this research. There are no direct benefits to participating in this study. Your participation is entirely voluntary. The interviews will take place at a neutral location. Your choice of whether you would like to participate, or not, will not influence your future relations with Ryerson University, the School of Early Childhood Education, or the agency where you are employed. You are not obliged to answer any questions you find objectionable and you are free to withdraw from the study without reasons at any point, and you may request removal of your data. You can withdraw by contacting the investigator (Marie Hodgson patricia.hodgson@rverson.ca 905-252-6168).

\section{Protecting your Identity:}

This research may result in publications of various types. Your name will not be attached to any form of the data that you provide, neither will your agency. A pseudonym will replace your name on all data that you provide to protect your identity. If the data are made available to other faculty or researchers for secondary analysis, your identity will never be disclosed. Any audio recordings made will be transcribed and then the tape will be destroyed.

I, agree to having the interview audio taped.

\section{Questions about the Study:}

If you have any questions about the study you may ask them now. If you have any questions later you may contact:

Investigator: Marie Hodgson patricia.hodgson@ryerson.ca 905-252-6168

Faculty: Dr. Rachel Langford, Director, School of ECE rlangfor@ryerson.ca 416 979-5000 extension 7635 


\section{Agreement:}

Your signature below indicates that:

- You have read the information in this consent agreement.

- You would like to participate in the study

- You are aware that you can withdraw this consent at any time during the study without penalty by contacting the investigator.

- You have been given a copy of this consent from with all contact information.

- You have been informed that by signing this consent form you are not giving up any of your legal rights.

Signature of Participant

Date

Signature of Researcher

Date 


\section{Appendix C}

\section{Script}

Hello 'Participant', this is Marie Hodgson calling.

I am currently completing my Master's Degree at Ryerson University in the field of Early Childhood Studies. I am about to begin the research component of the degree requirements and wondered if you would like to be a part of it.

I am looking for educational assistants who would be willing to complete a journal for 3-5 days and then allow me to interview them for approximately 1 hour at a neutral location.

We would discuss the daily requirements of your job and your reflections on your role as a support in the classroom.

Your identity will be kept confidential and the data will be destroyed after 5 yrs. Your participation is completely voluntary and if you are not comfortable taking part I will understand and respect your decision.

Take some time to think about it and let me know what you decide. Good bye. 


\section{Appendix D}

Interview questions

1. What is your job title?

2. How many years experience do you have?

3. Tell me a little about yourself and how you came to be an educational assistant.

4. What is your educational level?

5. Describe a typical day.

(a) What you do.

(b) Is it the same every day?

6. How do you feel about what you do each day?

(a) How do you feel when your schedule is changed at the last minute?

(b) What makes you feel that way?

7. What assignments have you enjoyed most this year?

8. What types of children with disabilities are in the general education classroom where you work? (a) What kind of training did you receive before working with this student? 
9. What kind of training has the school board provided?

10. What does the term 'inclusive education' mean to you?

(a) Do you think your school is inclusive?

(b) Why?

11. What are the major barriers that you face as an educational assistant?

(a) Describe your challenges.

12. What are the benefits that you have experienced as an educational assistant?

13. How would you like to be supported in your role as an educational assistant?

14. What would you like teachers to know about your place in the classroom?

15. What do you know about the policy around the educational assistant's job?

(a) Do you know the level of government responsible?

(b) Do you know where you would find out?

These are the questions we discussed in the interview. If you have anything further to add you may contact me at patricia.hodgson@ryerson.ca 


\section{References}

Ashbaker, B., \& Morgan, J. (2001). Growing roles for teachers' aides. Education Digest, 66(7), 60.

Bourke, P. (2009). Professional development and teacher aides in inclusive education contexts: Where to from here? International Journal of Inchisive Education, 13(8), 817-827.

Carnahan, C., Williamson, P., Clarke,L., \& Sorensen, R. (2009). A systematic approach for supporting paraeducators in educational settings: A guide for teachers. Teaching Exceptional Children, 4I(5), 34-43.

Corbin, J., \& Strauss, A. (1998). Basics of qualitative research: Techniques and procedures for developing grounded theory. Los Angeles, Calif.: Sage Publications, Inc.

Cremin, H., Thomas, G., Vincett, K. (2003). Learning zones: An evaluation of three models for improving learning through teacher/ teaching assistant teamwork. Support for Leaming, $18(4), 154-161$

Creswell, J. (2009). Research design: Qualitative, quantitative, and mixed methods approaches. Thousand Oaks, Calif:: Sage Publications.

Freire, A. \&. M.,D. (Ed.). (1998). The Paulo Freire reader. New York, N.Y.: The Continuum Publishing Co.

Friere, P. (1970). Pedagogy of the oppressed. New York, N.Y.: The Continuum Publishing Co. 
Friere, P. \& Faundez, A. (1989). Learning to question: A pedagogy of liberation. New York, N.Y.: The Continuum Publishing Co.

Giangreco, M, Edelman, S., \& Broer,S. (2001). Respect, appreciation, and acknowledgment of paraprofessionals who support students with disabilities. Exceptional Children, 67(4), 485.

Giangreco, M., Edelman, S., Luiselli,T., \& McFarland, S. (1997). Helping or hovering? Effects of instructional assistant proximity on students with disabilities. Exceptional Children, 64(1), 7.

Horne, P., \& Timmons,V. (2009). Making it work: Teachers' perspectives on inclusion. International Journal of Inclusive Education, 13(3), 273-286.

Hughes, T., \& Valle-Riestra, D. (2008). Responsibilities, preparedness, and job satisfaction of paraprofessionals: Working woith young children with disabilities. International Journal of Early Years Education, 16(2), 163-173.

Leithwood, K., \& Jantzi, D. (1999). Transformational school leadership effects: A replication. School Effectiveness \& School Improvement, 10(4), 451-479.

Marks, S., Schrader, C., \& Levine, M. (1999). Paraeducator experiences in inclusive settings: Helping, hovering, or holding their own? Exceptional Children, 65(3), 315.

Ministry of Education Ontario. (2005). Education for all: The report of the expert panel on literacy and numeracy instruction for students with special education needs, kindergarten to grade 6. 
Ministry of Education Ontario. (2007). The Education Act. Regulation 181/98.

Minondo, S., Meyer, L. \& Xin, J. (2001). The role and responsibilities of teaching assistants in inclusive education: What's appropriate? JASH- the Association for Persons with Severe Handicaps, 26(2), 114-119.

Patterson, K. (2006). Roles and responsibilities of paraprofessionals: In their own words. Teaching Exceptional Children, 2(5)

Sikes, P., Lawson, H., \& Parker, M. (2007). Voices on: Teachers and teaching assistants talk about inclusion. International Journal of Inclusive Education, II(3), 355-370.

Simcoe County District School Board (2008). Collective agreement between: Simcoe County District School Board and Ontario Public Service Employees Union. Retrieved July 15, 2010, from http://www.opseu330.com/docs/collective\%20agreement.pdf

Slee, R. (2001). 'Inclusion in practice': Does practice make perfect? Educational Review, 53(2), 113-123.

Takala, M. (2007). The work of classroom assistants in special and mainstream education in Finland. British Journal of Special Education, 34(1), 50-57.

Zigmond, N. (2003). Where should students with disabilities receive special education services? is one place better than another? Journal of Special Education, 37(3), 193-199. 